\title{
Flexible Carbon Capture and Utilization technologies in future energy systems and the utilization pathways of captured $\mathrm{CO} 2$
}

Mikuli, Hrvoje; Skov, Iva Ridjan; Dominkovi, Dominik Franjo; Wan Alwi, Sharifah Rafidah; Manan, Zainuddin Abdul; Tan, Raymond; Dui, Neven; Hidayah Mohamad, Siti Nur; Wang, Xuebin

\section{Published in:}

Renewable and Sustainable Energy Reviews

Link to article, DOI:

10.1016/j.rser.2019.109338

Publication date:

2019

Document Version

Peer reviewed version

Link back to DTU Orbit

Citation (APA):

Mikuli, H., Skov, I. R., Dominkovi, D. F., Wan Alwi, S. R., Manan, Z. A., Tan, R., Dui, N., Hidayah Mohamad, S. N., \& Wang, X. (2019). Flexible Carbon Capture and Utilization technologies in future energy systems and the utilization pathways of captured CO2. Renewable and Sustainable Energy Reviews, 114(109338), [109338]. https://doi.org/10.1016/j.rser.2019.109338

\section{General rights}

Copyright and moral rights for the publications made accessible in the public portal are retained by the authors and/or other copyright owners and it is a condition of accessing publications that users recognise and abide by the legal requirements associated with these rights.

- Users may download and print one copy of any publication from the public portal for the purpose of private study or research.

- You may not further distribute the material or use it for any profit-making activity or commercial gain

- You may freely distribute the URL identifying the publication in the public portal 


\title{
Flexible Carbon Capture and Utilisation Technologies in Future Energy Systems and the Utilisation Pathways of Captured $\mathrm{CO}_{2}$
}

\author{
Hrvoje Mikulčić ${ }^{* 1,2}$, Iva Ridjan $\mathrm{Skov}^{3}$, Dominik Franjo Dominković ${ }^{4}$, Sharifah \\ Rafidah Wan Alwi ${ }^{5}$, Zainuddin Abdul Manan ${ }^{5}$, Raymond Tan ${ }^{6}$, Neven Duić \\ Siti Nur Hidayah Mohamad ${ }^{5}$, Xuebin Wang ${ }^{1}$
}

${ }^{1}$ MOE Key Laboratory of Thermo-Fluid Science and Engineering, Xi'an Jiaotong University, Xi'an, Shaanxi, 710049, China e-mails: hrvoje.mikulcic@fsb.hr,wxb005@mail.xjtu.edu.cn

${ }^{2}$ Faculty of Mechanical Engineering and Naval Architecture University of Zagreb, Zagreb, Croatia e-mail: neven.duic@fsb.hr

${ }^{3}$ Aalborg Universitet, Aalborg, Denmark e-mail:iva@plan.aau.dk

\footnotetext{
${ }^{4}$ Technical University of Denmark, Department of Applied Mathematics and Computer Science, Lyngby, Denmark e-mail:dodo@dtu.dk

${ }^{5}$ Process Systems Engineering Centre (PROSPECT), Research Institute for Sustainable Environment/ School of Chemical and Energy Engineering, Faculty of Engineering, Universiti Teknologi Malaysia, Johor Bahru, Johor, Malaysia e-mails:syarifah@utm.my,dr.zain@utm.my,sn.hidayah@utm.my

${ }^{6}$ Chemical Engineering Department, De La Salle University-Manila, Manila, Philippines e-mail: raymond.tan@dlsu.edu.ph
}

\begin{abstract}
Future $100 \%$ renewable energy systems will have to integrate different sectors, including provision of power, heating, cooling and transport. Such energy systems will be needed to mitigate the negative impacts of economic development based on the use of fossil fuels, but will rely on variable renewable energy resources. As two-thirds of global greenhouse gas emissions can be attributed to fossil fuel combustion, decarbonization of energy systems is imperative for combating the climate change. Integrating future energy systems with $\mathrm{CO}_{2}$ capture and utilization technologies can contribute to deep decarbonization. As these
\end{abstract}

* Corresponding author. Tel.: +385 16168 494; fax: +385 16156940 .

E-mail address: hrvoje.mikulcic@fsb.hr (H. Mikulčić). 
technologies can be operated flexibly, they can be used to balance the grid to allow for high levels of variable renewable energy in the power mix. The captured $\mathrm{CO}_{2}$ can be either utilized as a feedstock for various value-added applications in the chemical industry and related sectors such as the food and beverage industries. This paper reviews the state-of-the-art literature on $\mathrm{CO}_{2}$ capture and utilization technologies, with an emphasis on their potential integration into a low-carbon, high-renewables penetration grid. The potential market size for $\mathrm{CO}_{2}$ as raw material is also elaborated and discussed. The review paper provides an insight to the development and the technological needs of different energy system sectors, as well the limitations, challenges and research gaps to the integration of the variable renewable energy sources and flexible carbon capture and utilization technologies.

Keywords: Carbon capture; Carbon utilization; Variable renewable energy sources; Future energy systems, Flexibility; 100\% Renewable energy systems

\section{Nomenclature}

APC - Aromatic polycarbonates

ASU- Air separating unit

BECCS - Bioenergy with carbon capture and storage

BEV - Battery electric vehicle

BDCL - Biomass direct chemical looping

BIGCC - Biomass-based integrated gasification combined cycle

$\mathrm{CaO}$ - Calcium oxide

CC - Carbon capture

CCGT - Combined cycle gas turbine

CCS - Carbon capture and storage

CCU - Carbon capture and utilization

CCUS - Carbon capture, utilization, and storage

CE - Circular economy

$\mathrm{CH}_{4}$ - Methane

CHP - Combined heat and power

CLC - Chemical looping combustion

$\mathrm{CO}_{2}$ - Carbon dioxide 
COP - Coefficient of performance

CUT - Carbon utilization technologies

DAC - Direct air capture

EOR/EGR - Enhanced oil and gas recovery

EU - European Union

EV - Electrical vehicle

FCEV - Fuel cell electric vehicle

GDP - Gross domestic product

GHG - greenhouse gas

GWP - Global warming potential

HRSG - Heat recovery steam generator

IEA - International Energy Agency

IGCC - Integrated gasification combined cycle

IL - Ionic liquid

IMF - International Monetary Fund

IPCC - Intergovernmental Panel on Climate Change

IS - Industrial symbiosis

LT PEM EC - Low-temperature proton exchange membrane electrolysis cell

MEA - Monoethanolamine

$\mathrm{N}_{2} \mathrm{O}$ - nitrous oxide

NET - Negative emissions technology

NG - Natural gas

PEM - Polymer electrolyte membrane

PHEV - Plug-in hybrid electric vehicle

PSA - Pressure swing adsorption

PtL - Power-to-Liquid

PtX - Power-to-X

PV - Photovoltaics

RES - Renewable energy sources

SGC - Series gas cooler

SNG - Syngas

SOEC - Solid-oxide electrolysis cells

TRL - Technology readiness levels

USA - United States of America 
UK - United Kingdom

VRES - Variable renewable energy sources

WHO - World Health Organization

Word count:14,210

\section{Introduction}

According the Intergovernmental Panel on Climate Change (IPCC) [1], global carbon dioxide $\left(\mathrm{CO}_{2}\right)$ emissions need to be reduced to zero by mid-century in order to ensure that temperature rise is limited to $1.5^{\circ} \mathrm{C} \mathrm{C}$ by 2100 . Carbon Capture, Utilization, and Storage (CCUS) can play an important role as a major technological wedge for achieving such deep reductions in emissions, along with other options such as energy conservation, use of renewable energy, and deployment of negative emissions technologies (NETs) such as bioenergy with carbon capture and storage (BECCS) and direct air capture (DAC).

Carbon Capture and Utilization (CCU) and Carbon Capture and Storage (CCS) are envisioned to play complementary roles within an integrated system that can approach zero emissions that are needed for climate stabilization in the medium-term future. CCU focuses on resource efficiency, and is aligned with the concept of Circular Economy (CE) that is currently being advocated from a policy standpoint in many regions and countries, including the European Union (EU) and China [2]. Engineering methodologies can be applied to facilitate the implementation of $\mathrm{CE}$ which can lead to resource conservation and climate change mitigation co-benefits [3]. Most CCU options do not result in permanent sequestration of carbon, so these benefits arise through other means. In particular, there is significant potential in the near future for flexible CCU systems to play a major grid balancing function via Powerto-X (PtX) pathways. Such PtX schemes can reduce the need for direct electricity storage with batteries by using virtual storage in the form of secondary products such as liquid or gaseous fuels [4]. This grid balancing function can enable higher levels of penetration of renewables in the power grid, which will allow emissions to approach near-zero level without undue volatility.

On the other hand, CCS (including BECCS and DAC) contributes to the climate picture through permanent geological sequestration of $\mathrm{CO}_{2}$. In order to have a significant contribution to mitigation efforts, sequestration needs to occur at much larger scale in comparison to the level of $\mathrm{CO}_{2}$ utilization in potential chemical and energy markets. Sequestration will be vital to 
enable negative emissions to be achieved in specific sectors or regions; such negative emissions will be needed to offset positive emissions that may occur elsewhere on the planet [5].

Both CCU and CCS can coexist in an integrated CCUS framework that results in mutual benefits from shared infrastructure. By providing value-added end use of $\mathrm{CO}_{2}, \mathrm{CCU}$ can also act as a catalyst for the initial development of distribution infrastructure that can be scaled up later as economic barriers to permanent geological storage of $\mathrm{CO}_{2}$ are overcome (e.g., via imposition of carbon tax in the future). Dual benefits accrue from direct reduction of $\mathrm{CO}_{2}$, and from the role of the system in enabling higher levels of utilization of variable renewable energy systems (VRES). The framework can be visualized as shown in Figure 1.

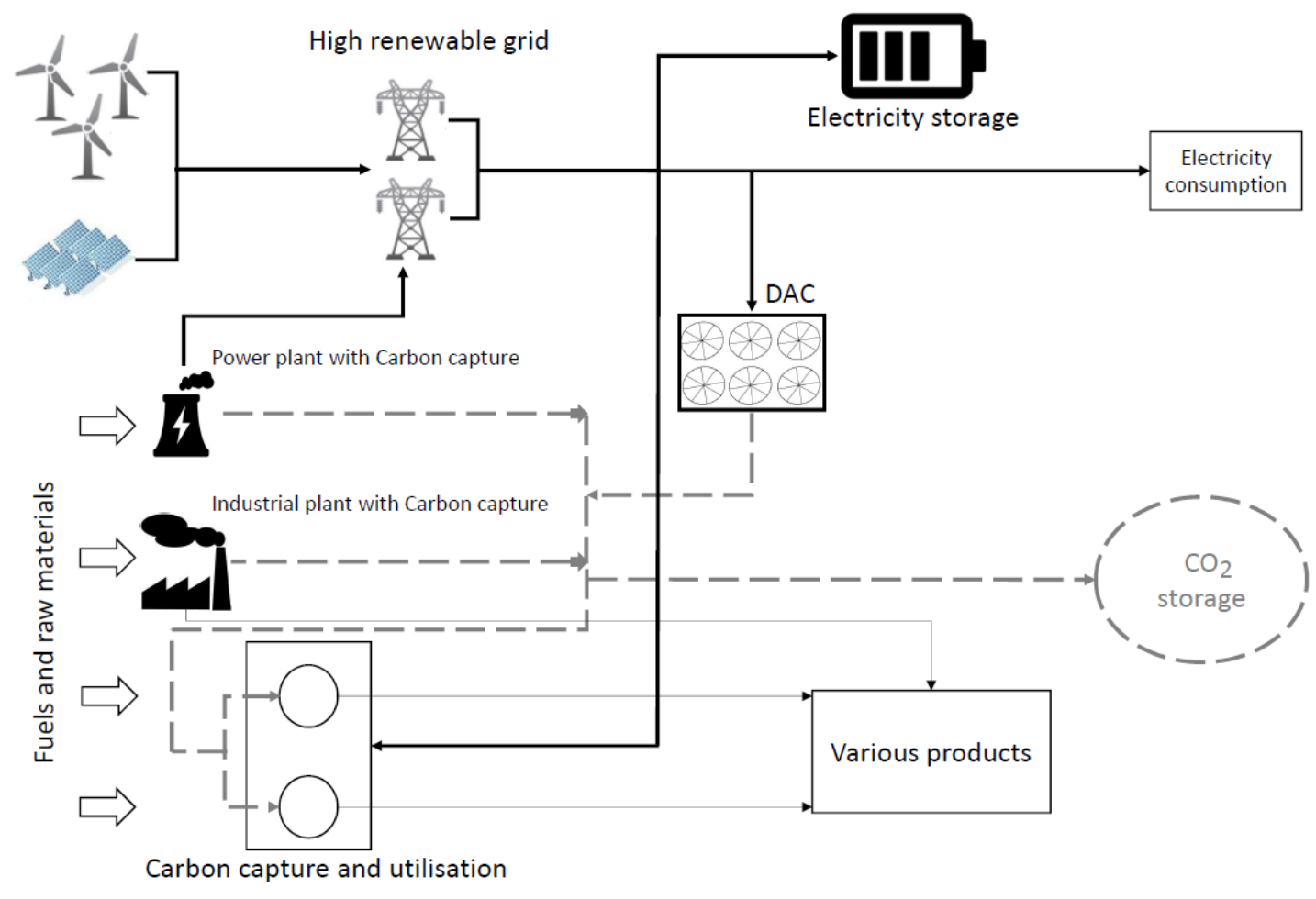

Figure 1. Integrated VRES based energy system and CCUS system

This review paper is intended to provide a survey on background issues, component technologies, and system-level integration of CCUS to achieve future energy systems that approach zero emissions. While other review papers on CCUS have been published, many of these previous papers are either technology-specific (Merino-Garcia et al., [6]) or 
geographically defined (Liu et al., [7]) in their scope. Recent review papers of comparable breadth of scope are listed in Table 1, and brief descriptions are given of the aspects that they emphasize. While Koytsoumpa et al. [8] also discuss PtX as a measure for grid stabilization, we provide a more in-depth analysis of integrating operations of CCUS with zero-emissions VRES through measures such as flexible capture and $\mathrm{PtX}$.

Table 1 Recent review papers on carbon capture and utilization

\begin{tabular}{|c|c|}
\hline Review Paper & Areas of Focus \\
\hline Marocco Stuardi et al. [9] & $\begin{array}{l}\text { - } \\
\text { - In situ utilization transformation }\end{array}$ \\
\hline Jarvis and Samsatli [10] & $\begin{array}{l}\text { - Value chains } \\
\text { - Physical infrastructure } \\
\text { - Techno-economic aspects of conversion } \\
\text { and utilization options }\end{array}$ \\
\hline Al-Mamoori et al. [11] & $\begin{array}{l}\text { - Capture techniques } \\
\text { - Utilization as feedstock for chemical } \\
\text { processes }\end{array}$ \\
\hline Koytsoumpa et al. [8] & $\begin{array}{l}\text { - Decarbonization of energy systems } \\
\text { through sequestration } \\
\text { - Utilization for fuel and energy production } \\
\text { - Integration of CCUS with energy storage }\end{array}$ \\
\hline Norhasyima and Mahlia [12] & 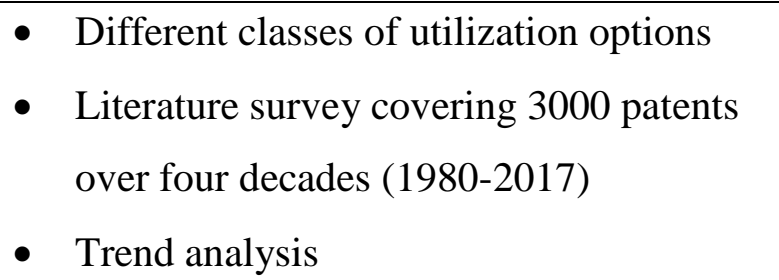 \\
\hline
\end{tabular}

\section{Method}

The research method is based on a three-step procedure, comprising (i) literature search and systematic review, (ii) grouping of studies and (iii) assessment of study relevance to flexible CCUS technologies, $100 \%$ RES energy system and $\mathrm{CO}_{2}$ utilization. The literature search on CCUS, $100 \%$ RES energy system and $\mathrm{CO}_{2}$ utilization was done by searching a scientific database. Results of the advanced search of the Scopus [13] databases by keywords, abstract 
and title that attempted to reflect these research topics are depicted in Figure 2. It can be seen that during the last decade research interest for CCUS, $100 \%$ RES energy system, and $\mathrm{CO}_{2}$ utilization has resulted with large numbers of published documents. These data can be interpreted as a sign that academic community, due to the climate change effect and need for lowering GHG emissions, is becoming increasingly aware of the significance of decreasing $\mathrm{CO}_{2}$ emissions and even going for negative $\mathrm{CO}_{2}$ emissions. 


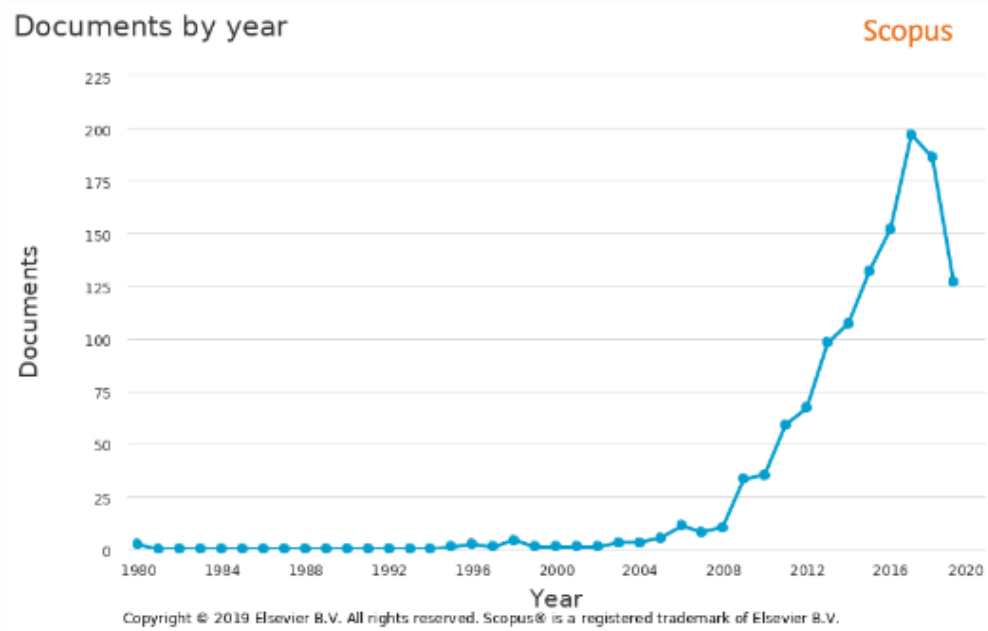

a)

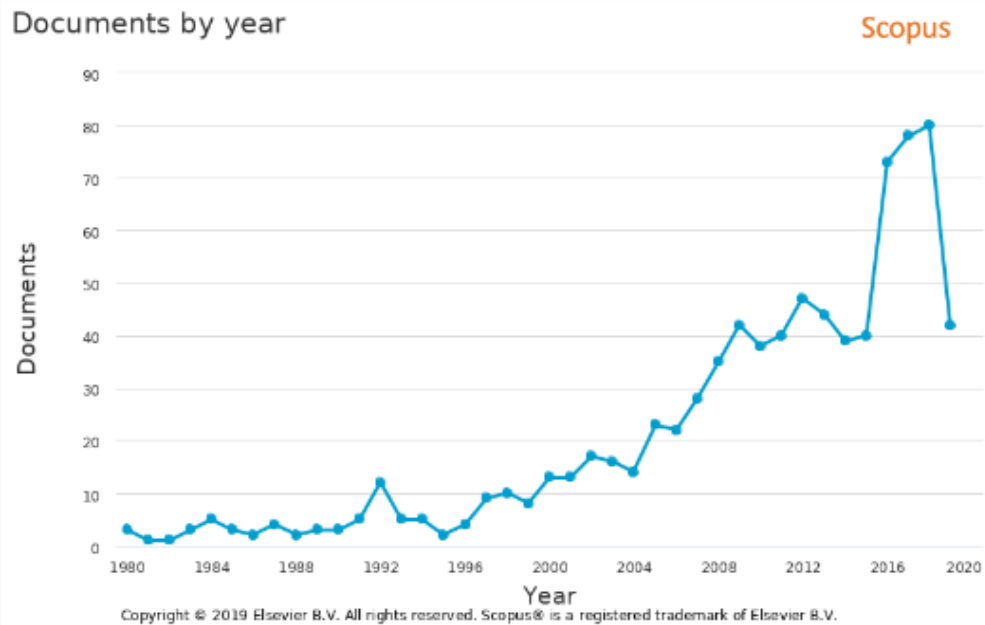

b)

Documents by year

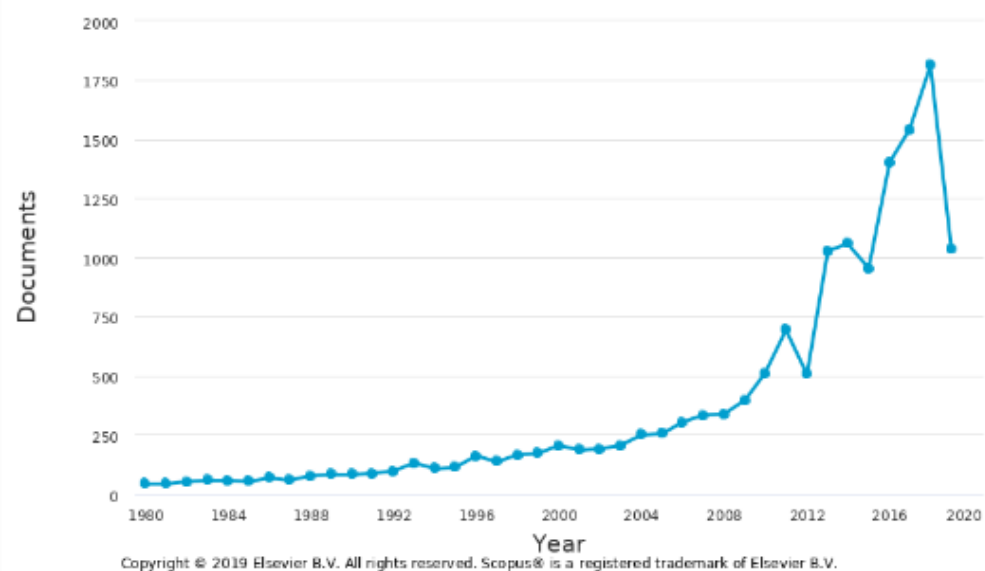

c) 
Figure 2. Results of advanced Scopus [13] database search by year: a) (TITLE-ABS-KEY: (carbon AND capture AND utilization AND storage)); b) (TITLE-ABS-KEY (100\% AND res AND energy AND system)); c) (TITLE-ABS-KEY (co2 AND utilization)).

\section{Future Energy Systems}

Combustion of fossil fuels to generate electricity and to provide heating, cooling and transportation services is a major contributor to emissions of greenhouse gases (GHGs) and air pollutants. Energy systems account for about two-thirds of global GHG emissions [14]. More than $80 \%$ of the world urban population live in areas with air quality levels below World Health Organization (WHO) recommendations [15]. Although carbon dioxide $\left(\mathrm{CO}_{2}\right)$ is responsible for $77 \%$ of radiative forcing [16], other GHGs are also generated by energy systems. In particular, methane $\left(\mathrm{CH}_{4}\right)$ and nitrous oxide $\left(\mathrm{N}_{2} \mathrm{O}\right)$ may be generated at various points (resource extraction, processing, transportation, storage and combustion) along fossil energy supply chains.

Although energy demand tends to increase with rising standards of living, $\mathrm{CO}_{2}$ emissions and Gross Domestic Product (GDP) growth can be decoupled, as illustrated in the case of Chinese households [17], in energy-intensive industry in Scandinavia [18], as well as for eight Western European countries [19]. However, this seems not to be the case for the transport sector [20]. The International Monetary Fund (IMF) showed that four advanced countries (i.e., Italy, Germany, the United States of America - USA and the United Kingdom $\mathrm{UK}$ ) decoupled GDP growth from $\mathrm{CO}_{2}$ emissions. However, four emerging economies that they assessed still have a strong coupling effect (i.e., Brazil, China, India and South Africa).

\subsection{Power Generation}

The main drivers in decoupling $\mathrm{CO}_{2}$ emissions and GDP growth are an increase in the grid share of low-carbon power generation sources, as well as the utilization of more efficient energy generation and utilisation technologies.

Greater public concern about the adverse impacts of energy systems, coupled with technological changes that have made alternative energy sources increasingly more affordable, has led to a notable shift towards the use of renewable energy [14]. From 2008 to 2017, the global installed capacity of renewable energy sources increased from 1.06 TW to 2.18 TW [21]. In 2017, the worldwide share of renewable energy generation in total power generation sector was $25 \%$ [22]. Out of the total renewable energy capacity installed, hydropower capacity amounted to 1.27 TW in 2017. Wind capacity increased more than fivefold from 2008 to 2017, 
from $0.1 \mathrm{TW}$ to $0.51 \mathrm{TW}$, while photovoltaics (PV) capacity increased more than 20 times in the same period, from $0.015 \mathrm{TW}$ to $0.39 \mathrm{TW}$. The main driver behind the dramatic increase in installed capacity of PV and wind turbines has been a significant price drop. Between 2010 and 2017 , the price of PV dropped by $80 \%$, while the price of wind turbines reduced by $50 \%$ over the same period [23]. It is expected that these technologies will continue to dominate the renewable energy installation portfolio in the future [24].

Increase in power generation demand under the current policies scenario is set to increase by more than 25\% until 2040 according to the International Energy Agency (IEA) [22]. However, by implementing different policy measures, it is possible to achieve $100 \%$ renewable energy systems by the year 2050. Use of $100 \%$ renewable energy for all sectors, and not only renewable power sectors, was shown to be both technically and economically feasible, among other countries and regions, in South-east Europe [25], the EU [26] and the USA [27].

Energy systems based on $100 \%$ renewable energy sources have been the subject of extensive debate in the scientific literature. One paper criticized renewable energy models as not having fine enough spatial resolution and potentially having erroneous assumptions in energy models [28]. A rebuttal claiming that the original modelling assumptions were correct was later published [29]. Another review paper of renewable energy system based research papers claimed that papers they reviewed are technically unviable, mostly due to unrealistic energy-demand forecasts [30]. However, the latter paper was disputed in an article pointing out the misunderstanding of the energy conversion processes in energy systems, as well as accounting methods for the primary energy supply of renewable energy sources [31]. The latter paper explicitly answered point by point all the concerns raised by Hearda et al. [30], by referring to the relevant literature. It has concluded that energy systems based on renewable energy sources are feasible, and already economically viable.

Future energy systems will continue to utilize ever increasing levels of renewable energy sources. Moreover, the future energy systems are set to a more integrated pathway both between different sectors, such as power and heat [32], power and gas [33], and power and mobility [34], as well as within different sectors, such as within distributed district heating grids [35]. This cross-sectoral approach also identified as smart energy system [36] maximises interconnections between the sectors, resources and demands with the use of storage technologies in order to improve the energy system flexibility and enables higher integration of renewable energy (see Figure 3). 


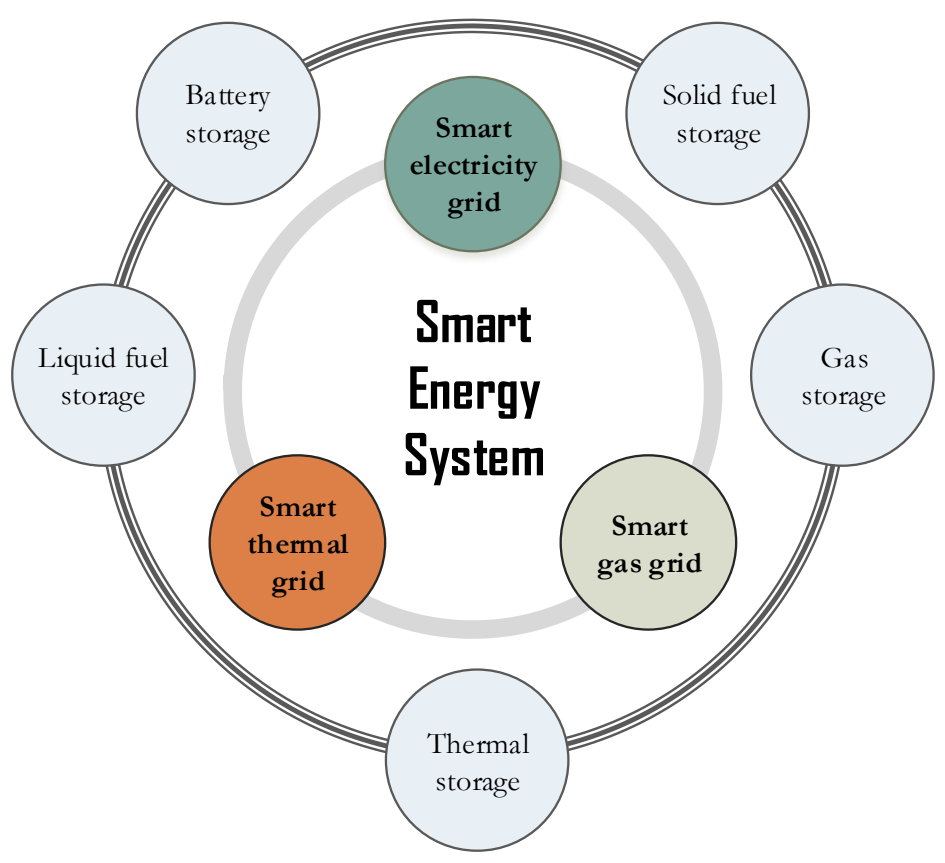

Figure 3. Smart energy system concept, adapted from [37]

Simulations have shown the possibility of achieving energy systems with zero carbon emissions by 2050. Mathiesen et al. [36] carried out a pre-feasibility study showing that the $100 \%$ renewable energy system could be achieved for the whole European Union by integration of different energy sectors. Similarly, $100 \%$ renewable energy systems were simulated for the case of Denmark [38], Portugal [39], Ireland [40], and Croatia [41]. Moreover, a zero-carbon energy system was simulated for the whole South-east Europe [25]. All of those papers showed that future energy systems will be based on variable renewable energy sources, mostly onshore and offshore wind, and photovoltaics (PV). The same papers showed that in the last phase of energy transition, a certain capacity of electrolysers will be needed in order to provide additional flexibility to the energy system. In two studies for Denmark, the capacities of electrolysis must reach up to $9000 \mathrm{MW}$ in order to provide fuels for the transport sector and industry in $100 \%$ renewable energy systems [42]. Similar behaviour can be seen in smaller island-states or city-states. For the case of Singapore, one of the scenarios showed that future energy system could meet $80 \%$ of final electricity demand by variable renewable energy sources, while $6 \%$ of the final electricity demand was used for solid-oxide electrolysis cells (SOEC) [43]. Similarly, for the case of Aruba, an island state located in the Caribbean, $78 \%$ of the final electricity demand could be met by variable renewable energy sources by 2020 [44].

The increasing penetration of variable renewable energy sources (VRES) has shown the increasing need for a flexible energy system. As old fossil fuel plants are retired, flexible power 
plants will need to be built to supply electricity when VRES is not available. Due to VRES penetration, in certain time periods there is an excess of electricity that is not exportable, and the spot market electricity prices become very low or even negative. The economically valuable utilisation of such surplus electricity presents an important opportunity [45]. One of the most promising and appropriate solution for such electricity is energy storage. A crucial aspect is that conversion systems must be market controlled [46], and that different types of stakeholders can participate in that market [47].

It has been long debated if carbon capture is a sustainable solution. Carbon capture from stationary $\mathrm{CO}_{2}$ emitting installations is a technology that can drastically reduce the emissions to the atmosphere. There are two ways the captured $\mathrm{CO}_{2}$ can be handled. One is to geologically store it via Carbon Capture and Storage (CCS), and the other is to reuse it as a new resource via Carbon Capture and Utilisation (CCU). It is arguable that CCS as a technology can enable the prolonged use of fossil fuels. Additionally, CCS is not very suitable for a $100 \%$ RES energy system that is based on VRES since these plants operate as baseload production, and require increased fossil fuel consumption for capture processes [48]. Compared to CCS, CCU provides different and more sustainable products/services, and integrates different systems using waste from one as a resource to the other. $\mathrm{CCU}$ can be viewed from the perspective of being an enabling technology component for future $100 \%$ RES carbon-free energy systems. Viewed from the perspective of the energy generating system, power-to-gas and power-to-fuel CCU options provide the electrofuels that are long term high density energy storage. The electrofuels can be used by heavy-duty vehicles, ships, airplanes, and by Combined Cycle Gas Turbine (CCGT) or engines operating in Combined Heat and Power (CHP) mode to provide electricity and heat when there is no other renewable energy source available. 


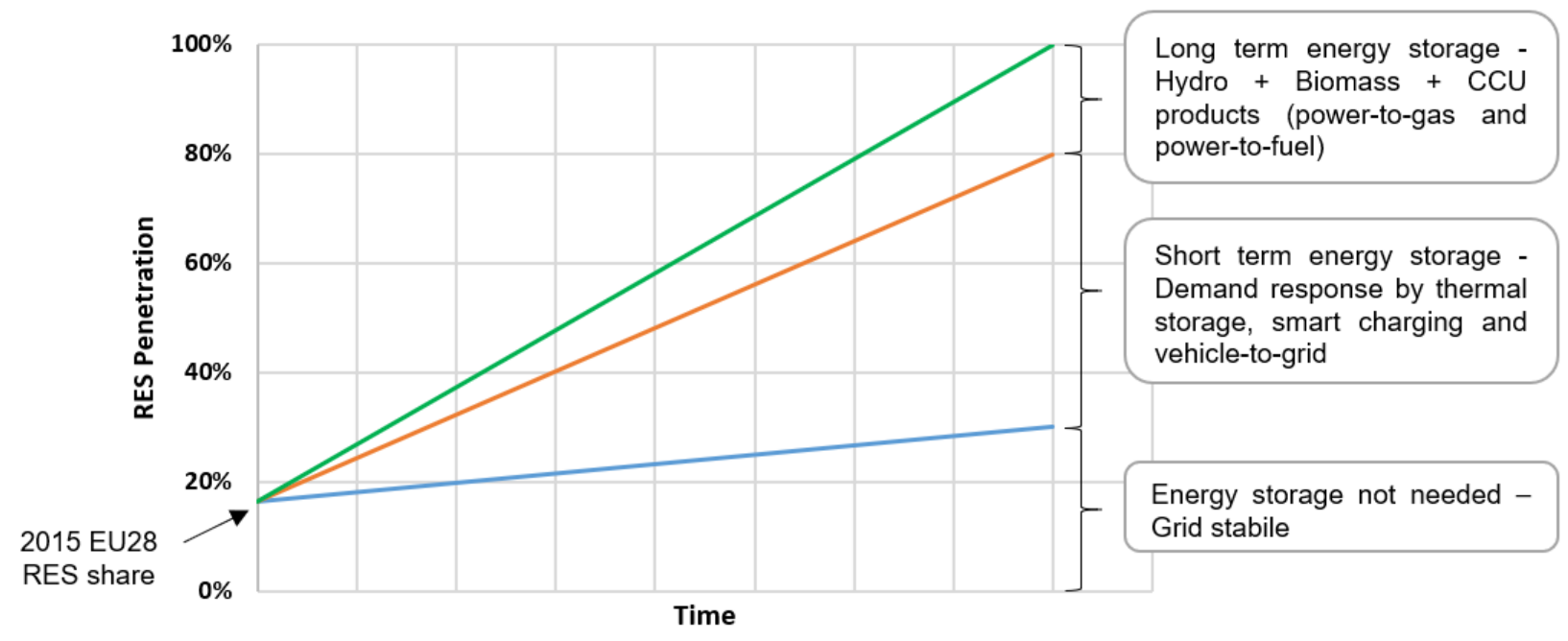

Figure 4. Penetration of RES into EU28 power system over time, adapted from [49]

The deployment of CCU as a technology depends on the penetration of RES in the power system. In the EU, it was 16.7 percent in 2015 [50]. The penetration of around 30\% of RES can be balanced by the grid. Up to approximately $80 \%$ of VRES penetration, the volatility can be balanced by demand response, which includes short term storage, thermal storage and batteries in electric vehicles [51]. Increasing penetration further presents a greater challenge (see Figure 4.), as they need to be handled by long term energy storages. Long term energy storage technologies include the chemical energy stored in electrofuels produced by CCU, together with hydro and biomass. Hydro and biomass offer the best option for storing renewable energy when it is produced and releasing it, with simple and affordable technology, when there is a demand. However, using only hydro and biomass is not always sufficient for covering this remaining $20 \%$ gap, as there may not be enough of these resources in some countries or regions (e.g., the whole EU) [36]. This gap can be solved by flexible CCU; however, CCU should be used only as a last energy storage option since it has the highest marginal cost. The precondition of CCU use is that there is an excess of zero-carbon electricity, meaning that CCU is to be used only with electricity generated by RES sources. Due to the expected increased penetration of VRES, CCU needs to operate in a flexible manner. Dual benefits accrue from both direct removal of $\mathrm{CO}_{2}$ from exhaust gases, as well as its role as an enabler of high penetration of renewables into the grid power mix.

\subsection{Transport}


Transport is a sector that is responsible for a large share of primary energy demand, as it accounts for $22 \%$ of end-use energy demand worldwide [52]. While it is expected that energy demand for cars and trucks will grow slowly until 2040, energy demand for aviation transport is expected to rise significantly until the year 2040, by up to $63 \%$ according to one of the scenarios [52]. With EU-28 goals to reduce the GHG emissions in transport by $67 \%$ in 2050 [53], commercialization of new technologies that can offer high-efficiency improvements, low carbon liquid fuels and modal shift will be necessary. Decreasing transport demand and modal shifts are an essential part of the long term transport sector planning. Decreasing transport demand by changes in the transport infrastructure and via car-sharing is a necessary step to a $100 \%$ renewable energy in transport sector [54]. According to Anable et al. [55], radical changes in lifestyle can lead to a 74\% reduction in distance travelled by cars in 2050 .

Electrification of transport is the most promising technological solution for the sector, because the electric motor is much more efficient than the internal combustion engine; electric cars are 3.5 times more efficient, and electric buses are 2.5 times more efficient than their internal combustion counterparts [44]. The advantage is further compounded because electricity can be generated using various low-carbon sources. However, not all transportation modes can be directly electrified by the currently available technology. One study showed that for the case of the European Union, $72.3 \%$ of the transport energy demand could be directly electrified by the existing technology [56]. Electrification of road transport can bring demand reductions of $\sim 70 \%$ with the use of battery-driven vehicles [52]. In the period from 2010 to 2017 , electric car stock (BEV and PHEV) has increased more than 200 times [57]. For the case of Denmark, the authors assumed that $50 \%$ of the transport sector could be directly electrified, although they did not carry out a detailed technical assessment of the transport sector [36]. Another positive aspect of electrification of the transport sector is that it can serve as an integration point for other energy sectors, such as power and gas. One paper showed that smart charging and vehicle-togrid usage can reduce $\mathrm{CO}_{2}$ emissions and the amount of curtailed renewable energy by half, in an energy system with large penetration of VRES [58]. At the city level, Šare et al. [59] showed that smart charging can reduce curtailed renewable energy by $7.5 \%$ in an urban energy system with a large share of VRES. However, the high penetration of electric vehicles can be achieved only with the right policies and incentives in place [60]. Electric ferries are emerging in the Scandinavian area, where the market share of current domestic ferry market could reach up to $80 \%$ [61]. According to Connolly [62], implementation of eRoad technology in combination with BEV for road transport can offer investment savings. 
For long distance transportation, heavy-duty transportation, marine, and air transportation, direct electrification is not a feasible solution with currently available technology, different alternatives will play a role in future transport energy systems. For the remainder of the transport sector that is not suited to electrification, several alternatives have been proposed, such as biofuels, hydrogen, electrofuels, or a combination of these technologies [56]. The use of hydrogen will most likely emerge as the range extender option FCEVs [63]; however, the maturity of the vehicle technology, costs and need for infrastructure expansion coupled with renewable production of hydrogen are the main barriers for large scale implementation. The projected share of hydrogen fuel in EU-28 in 2050 is only 5\% [64]. According to Jacobson et al. [65], hydrogen can meet the residual transport demand left after high electrification share. Biogas or liquefied methane can be used for supplying heavy-duty trucks, buses and ships. Even with improvements in gas vehicles, the direct use of biogas for electricity or heat production is more beneficial [66]. Second-generation biofuels for road transport by gasification of woody biomass in form of methanol and syngas (SNG) show good cost-performance according to [67]. The scarcity of sustainable biomass resources will inevitably be an issue that will limit the use of traditional biofuels in the transport sector [34]. Biomass scarcity, coupled with the increased level of variable renewable electricity, will increase the need for chemical storage of electricity in form of liquid or gaseous fuels so-called electrofuels [68], which can increase the flexibility of the overall energy system and help the integration of variable renewable sources. Biojet fuels are most commonly suggested alternatives for the aviation sector [69] and can contribute to the $\mathrm{CO}_{2}$ emission reductions [70]. Other option is production of jetfuels for aviation [71] via power-to-liquid (PtL) pathway [72].

\subsection{Industry}

The industrial sector accounts for $21 \%$ of global GHG emissions [73]. Reduction of emissions from industry is challenging due to the existence of many different subsectors. Process efficiency and energy efficiency improvements in the industry are important first steps in transitioning the industry to a more sustainable and low-carbon future. Electrification of the industrial sector and production of hydrogen and hydrocarbons with power-to-liquid and power-to-gas technologies could be one of the transitional pathways [74]. Luh et al [75] showed that single measures have a limited impact on the decarbonisation of the industrial sector, but the integrated approach can make a greater difference. 
The large demand for conventionally produced ammonia in the petrochemical industry, which is mainly used in fertilizers, could be displaced by green ammonia produced by using electrolytic hydrogen; this technology can also serve as a form of electricity storage [76]. The fossil-free iron and steel production by using hydrogen-based fuels has potential, once the required technology matures [77]. Brown et al [78] gave an overview of mitigation technologies that can be implemented in order to reduce $\mathrm{CO}_{2}$ emissions from heavy industry. Implementation of the circular economy (CE) can play an important role in the future of the manufacturing industry with the right framework in place [79]. Concepts such as industrial symbiosis (IS), where the exchange of resources across multiple industries in the same geographic area can reduce the dependence of primary raw materials, and help enhance industrial sustainability [80]. The cement industry is particularly problematic due to inherent $\mathrm{CO}_{2}$ emissions. Cement industry decarbonizing pathways are given in [81].

\subsection{Agriculture}

In 2015, agriculture represented (crop and livestock production) 9.58\% of the EU-28 GHG emissions, of which the biggest contributors were enteric fermentation and agricultural soils [82]. Using the largest three available global datasets, the authors in [83] showed that the share of agriculture in the total global anthropogenic GHG emissions was $11.2 \% \pm 0.4 \%$ in 2010, compared to $11.5 \% \pm 0.3 \%$ in 2000 and $12.3 \% \pm 0.6 \%$ in 1990 . For the EU, in order to meet the $2{ }^{\circ} \mathrm{C}$ target, the EU will need to focus on nitrous oxide $\left(\mathrm{N}_{2} \mathrm{O}\right)$ and methane $\left(\mathrm{CH}_{4}\right)$ emissions reduction in the agriculture sector [84]. Some of the technological advancements and increased efficiencies that could help curbing GHG emissions in the agriculture sector are nitrification inhibitors, feed additives for ruminants, and covering and flaring of slurry facilities [84]. Another opinion paper claimed that the currently plausible technologies will not be enough to meet the climate targets and that the development of such as methane inhibitors will be needed [85]. More efficient use of nitrogen fertilizers will needed to be achieved, as one large meta-analysis showed that $\mathrm{N}_{2} \mathrm{O}$ emissions grow exponentially as nitrogen inputs exceed crop needs, and not linearly as it was often assumed [86]. Reduction of GHG emissions from agriculture has several difficulties, mostly connected to quantification of actual levels of emissions [87].

Literature on relations between carbon emissions, economic growth and energy consumptions is very limited [88]. Study by Liu et al [89] looked into the impact of renewable energy and agriculture on the carbon emissions showing that organic agriculture systems have 
positive impacts on reduction of $\mathrm{CO}_{2}$ emissions. Somewhat contrary, one large meta-analysis of life cycle emissions that included 742 agricultural systems showed that organic agriculture require more land, use less energy but have similar GHG emissions as conventional systems [90]. Qiao et al [91] shows that agriculture significantly increases $\mathrm{CO}_{2}$ emissions in G20 countries, while confirming the positive effect of renewable energy on the $\mathrm{CO}_{2}$ emissions. Bidirectional causality has been shown between agricultural emissions and agricultural economic growth [92]. Moreover, renewable production of ammonia by PtX for fertilization purposes can further decrease the emission levels [93].

In order to reduce the emissions, changes in the diets from the consumer side are a necessary step, as the highest pollutants are the production of meats [94]. In the EU, reducing the GHG emissions in the agriculture sector alone will not be enough to meet the climate targets, and changes in diet will be unavoidable [84]. Switching to lower impact foods offer the largest potential for reducing GHG emissions in the agriculture sector, which includes avoiding ruminant meats and increased use of plant-based foods [90]. Ruminant meats have around 100 times the impact of the plants food [90]. Although the agriculture is an important sector from the climate change point of view and related emissions, it has limited potential for using in connection with CCUS, as its most important GHGs include $\mathrm{CH}_{4}$ and $\mathrm{N}_{2} \mathrm{O}$.

\section{Carbon Capture}

This section describes the major technologies for $\mathrm{CO}_{2}$ capture, including precombustion capture, oxyfuel combustion, chemical looping combustion (CLC), postcombustion capture, capture from fermentation processes, and direct air capture (DAC). There has been extensive growth in $\mathrm{CO}_{2}$ capture technology, as evidenced by a 2013 analysis of the patent landscape by Li et al. [95]. This paper covered over 1,000 patents (including more than 600 from the year 2000 onwards), indicating accelerating commercial interest in these technologies. Of these patents, $37.5 \%$ were on solvent-based systems, $35.5 \%$ on sorbent-based systems, and $27 \%$ on membrane-based systems. Although the bulk of the initial existing scientific and patent literature applies to $\mathrm{CO}_{2}$ capture from fossil fuel combustion [96], many of the same techniques can be adapted to systems involving combustion (or co-combustion) of biomass in Bio-Energy with Carbon Capture and Storage (BECCS) systems, with consequent changes in performance levels. BECCS can be implemented via direct firing of biomass in dedicated plants, or co-firing of biomass with fossil fuels as an interim measure [97]. Bhave et al. [98] reported a techno-economic assessment of eight mixed and dedicated BECCS schemes. 
The four dedicated biomass schemes were based on pre-, post-, oxy-, and chemical looping combustion systems. Capture cost was estimated for $50 \mathrm{MW}$ plants at $€ 145-185 /$, with CLC being the least expensive and pre-combustion systems being the costliest. For these options, technology maturity was assessed at Technology Readiness Levels (TRL) of 4-5 [98]. In Table 2 , the technology readiness level of carbon capture technologies is given.

Table 2 Technology readiness level of Carbon capture technologies, adopted from [99]

\begin{tabular}{|c|c|c|}
\hline $\begin{array}{c}\text { Technology readiness } \\
\text { level }\end{array}$ & TRL & Proposed technology \\
\hline Concept & TRL1 & \\
\hline Formulation & TRL2 & \\
\hline Proof of concept & TRL3 & $\begin{array}{l}\text { - } \text { Post-combustion Ionic liquids } \\
\text { - } \text { BECCS power } \\
\text { - Pre-combustion treatment } \\
\text { - } \text { Membranes dense inorganic }\end{array}$ \\
\hline Lab prototype & TRL4 & - Oxy-combustion gas turbine \\
\hline Lab-scale plant & TRL5 & \\
\hline Pilot plant & TRL6 & $\begin{array}{ll}\text { - } & \text { Membranes polymeric (power } \\
\text { plants) } \\
\text { - }\end{array}$ \\
\hline Demonstration & TRL7 & $\begin{array}{ll}\text { - } & \text { Membranes polymeric (NG } \\
\text { industry) } \\
\text { - Pre-combustion IGCC+CCS } \\
\text { - Oxy-combustion coal power } \\
\text { plant } \\
\text { - Post-combustion adsorption } \\
\text { - } \text { BECCS industry } \\
\text { - } \text { Direct Air Capture (DAC) } \\
\end{array}$ \\
\hline $\begin{array}{l}\text { Commercial refinement } \\
\text { required }\end{array}$ & TRL8 & \\
\hline Commercial & TRL9 & $\begin{array}{l}\text { - } \begin{array}{l}\text { Post-combustion amines (power } \\
\text { plants) }\end{array} \\
\text { - } \quad \text { Pre-combustion NG processing }\end{array}$ \\
\hline
\end{tabular}

\subsection{Pre-combustion $\mathrm{CO}_{2}$ capture}

Pre-combustion capture of $\mathrm{CO}_{2}$ in integrated gasification combined cycle (IGCC) plants is one of the major technology options for "greenfield" projects (i.e., new power plants). Gasification products are made to undergo the water-gas shift reaction to give a mixture of $\mathrm{CO}_{2}$ and $\mathrm{H}_{2}$. The former gas is then separated for capture and subsequent use or storage, while the 
latter is used as fuel in a CCGT plant [100]. For such plants, parasitic energy losses are incurred for the generation of $\mathrm{O}_{2}$ in an air separating unit (ASU) and for $\mathrm{CO}_{2}$ removal from the syngas. In addition to electricity, IGCC plants can also be used for polygeneration of various chemical or fuel products [101]. Process simulations involving multiple biomass feedstocks co-fired in IGCC plants for electricity generation and biofuel production via Fischer-Tropsch synthesis indicated significant opportunities for optimization via fuel blending [102]. Techno-economic analysis of a biomass-based integrated gasification combined cycle (BIGCC) plant using air and with an amine-based capture process for removing $\mathrm{CO}_{2}$ from syngas was recently reported by [103]. Their results show that efficiency can be optimized by using air to eliminate the need for an energy-intensive Air Separation Unit (ASU), and by introducing a heat recovery steam generator (HRSG).

\subsection{Oxyfuel combustion}

Oxyfuel combustion is a technique for generating $\mathrm{CO}_{2}$-rich flue gas by burning fuel in the absence of nitrogen [104]. This approach requires the use of an ASU to produce the oxygen needed for combustion; operation of the ASU, which is usually based on cryogenic separation or pressure swing adsorption (PSA), is highly energy intensive and creates a parasitic electric power load that leads to reduced power plant output and efficiency. Part of the $\mathrm{CO}_{2}$-rich flue gas is recycled and mixed with the oxygen stream to simulate the thermal ballast effect that would normally be played by $\mathrm{N}_{2}$, keeping the flame temperature and radiative profile close to conventional flame conditions [105]. Oxy-fuel combustion has been extensively studied for use with fossil fuels [106], although the technique has also been tested for coal-biomass blends [107]. Höltl et al. [108] point out that the oxyfuel combustion can provide favorable conditions for burning fuels of low calorific value, such as biomass from agricultural or municipal wastes. The rate of flue gas recycling can be adjusted to account for the effect of reduced flame temperature during biomass combustion [109].

\subsection{Chemical Looping Combustion}

Chemical Looping Combustion (CLC) systems make use a solid oxygen carrier which recirculates between air and fuel reactors to achieve combustion in the absence of nitrogen without excessive energy penalties [110]. In a CLC system, the carrier is typically based on metal oxides, which oxidizes in contact with air in the air reactor; its oxygen content is then used to burn the fuel in the fuel reactor, as it is reduced back to its initial state [111]. However, 
recirculation of the carrier results in eventual deterioration through mechanical attrition. As fuel combustion occurs without direct contact with air, the resulting combustion products consist mainly of $\mathrm{CO}_{2}$ and water vapor. Removal of this moisture content leaves a high-purity $\mathrm{CO}_{2}$ stream which is ready for transport for subsequent storage or utilization. While CLC was originally proposed for use with gaseous fuels, particularly natural gas (NG), the scheme can also be used in BECCS systems. One option is to first gasify the biomass, and then to use the resulting volatile product in conventional CLC systems [112]. Direct use of particulate solid fuels in CLC has also been explored [113]. Song and Shen [114] review different configurations of CLC reactor systems designed for solid fuels. Typical problems in such systems include mechanical attrition of carrier particles and carbon residue deposition. Techno-economic analysis by Cormos [115] of a biomass direct chemical looping (BDCL) scheme using wood as fuel indicated that thermal efficiency of $42 \%$ can be achieved in a highly integrated process, even at $\mathrm{CO}_{2}$ capture rate of $99 \%$. This level of performance was shown to be clearly superior pre- and post-combustion BECCS plants to in the same work.

\subsection{Post-combustion $\mathrm{CO}_{2}$ capture}

Currently post-combustion capture involves capture of $\mathrm{CO}_{2}$ from flue gas via a scrubbing process, membrane $\mathrm{CO}_{2}$ capture, cryogenic $\mathrm{CO}_{2}$ capture and other niche capture options for specific industries. For example, high-quality $\mathrm{CO}_{2}$ is a byproduct of bioethanol production, and its capture is already commercially viable [116]. Techno-economic analysis of $\mathrm{CO}_{2}$ capture in bioethanol plants with gas-fired boilers shows that reduction in $\mathrm{CO}_{2}$ can be doubled by integrating $\mathrm{CO}_{2}$ capture from the boiler flue gas, at the expense of a $40 \%$ increase in fossil fuel consumption due to parasitic consumption of the capture system [117].

\subsubsection{Amine scrubbing}

Amine scrubbing is the mature and commercially viable technique for capturing carbon dioxide. It is widely used method for the post combustion treatment of the flue gas [118]. Procedure is based on the chemical absorption where amino-based absorbents are added from the top of an absorber to react with $\mathrm{CO}_{2}$ from the flue gas. Solution enriched with the $\mathrm{CO}_{2}$ molecules is then introduced to the stripper column to release captured $\mathrm{CO}_{2}$ [119]. As an absorbents metal carbonates can be used as well, but their price significantly affects wider usage of them [120]. Process is highly efficient in terms of capturing $\mathrm{CO}_{2}$ and efficiency can be up to 98\%. Nevertheless, heavy consumption of amino-based solvents enhances the corrosion 
processes on the used equipment and even more, high energy input is required for the solvent regeneration [118]. High energy input for the solvent regeneration implies high energy penalty and decline of the power plant efficiency, which can be up to $30 \%$. For example, for a baseline efficiency in a coal-fired power plant of about $38 \%, \mathrm{CO}_{2}$ capture reduces efficiency. to only $31 \%$ [121]. This energy penalty provides the basis for flexible operation of capture systems, and will be discussed in the next section. In addition, degradation of the solvent leads to the decrease of the absorption capacity and increment in overall operating costs [118]. Flexibility and economic feasibility of an amine scrubbing can be achieved if the degraded solvent is stored when the electricity prices are high and solvent regeneration is performed when electricity prices are lower. In general, it can be stated that decoupling of the power generation and $\mathrm{CO}_{2}$ capturing will result with reduced energy penalty and better economic performance of the system [121].

Chemical absorption processes for $\mathrm{CO}_{2}$ capture that make use of amines, such as monoethanolamine (MEA), have been extensively studied and is considered to be the most promising near-term technological option [122]. A major technical challenge in amine-based systems is the parasitic energy consumption in the recovery loop. Process integration principles have been used to optimize heat recovery and minimize energy losses in MEA-based systems [123]. For example, Le Moullec and Kanniche [124] studied different flowsheet configurations and identified options that can reduce power plant efficiency penalty by as much as $30 \%$. Amine degradation under normal flue gas conditions is also known to be a major issue [125]. Puxty et al. [126] did a screening study of 76 candidate amines, of which seven compounds were found to have good properties for $\mathrm{CO}_{2}$ capture applications. It should be noted that amine-based postcombustion capture for BECCS is less efficient than CCS with fossil fuels (and also less so than oxy-fuel based BECCS) and is also highly sensitive to biomass moisture content [127]. In addition to amines, $\mathrm{CO}_{2}$ capture using aqueous ammonia solution is inherently more efficient due to the low energy requirement for regeneration; for this reason, coupled with the widespread use of ammonia, this option also has lower costs than amine-based capture systems. On the other hand, disadvantages include higher potential for fugitive ammonia emissions and equipment corrosion [128]. Ionic liquids (ILs) are alternatives to amines, and offer significant advantages such as better chemical stability; use of ILs in the absence of water can also reduce parasitic energy requirement of capture systems [129].

\subsubsection{Membrane $\mathrm{CO}_{2}$ capture}


Membranes are among the most promising environmentally friendly technology for the recovery of $\mathrm{CO}_{2}$ emissions [130]. They have been proven highly efficient when the concentration of $\mathrm{CO}_{2}$ in flue gas is not below $10 \%$, while optimal economic competitive requirements are achieved for the concentrations of $20 \%$ of $\mathrm{CO}_{2}$ in the flue gas [131]. The introduction of polymeric membranes resulted in a significant boost in membrane deployment [132]. Use of polymer materials decreased the cost of membrane production and simplified handling requirements. Nevertheless, polymeric membranes are prone to the degradation, especially at higher pressures and temperatures. Since the fundamentals of this process are based on the pressure difference between inlet and exit, several limitations arise when the polymeric membranes are used. Firstly, low concentrations of the $\mathrm{CO}_{2}$ in the treated gas will lead to the low partial pressures, which affects process efficiency [131]. Moreover, elevated temperatures and higher pressure can cause swelling (plasticization) of the polymer material, which results in lower selectivity and increased permeability for all gases. Since the trade-off between permeability and selectivity is a key driver for efficient $\mathrm{CO}_{2}$ capture, precise optimisation of those two parameters is essential. Feasibility and competitiveness of this technology is expected when the permeability between $1000-10000$ Barrer and $\mathrm{CO}_{2} / \mathrm{N}_{2}$ selectivity between 50-200 is achieved [133]. More recently, composite membranes made of polymer and some inorganic material (ceramic, zeolites) are being investigated since they can be used at elevated temperatures and slightly higher pressures, which can extend overall membranes applicability [134]. Membrane-based separations processes are used extensively in many industrial applications, but their propensity to degrade at elevated temperature and in the presence of acid gases (e.g., $\mathrm{NO}_{\mathrm{x}}$ and $\mathrm{SO}_{2}$ ) is a major obstacle to their application for $\mathrm{CO}_{2}$ capture from combustion products [135].

\subsubsection{Cryogenic $\mathrm{CO}_{2}$ capture system}

Cryogenic $\mathrm{CO}_{2}$ capture is also a competitive technology for industrial sites where there is available excess cold energy, and offer advantages of giving a high purity product stream that may be needed by downstream $\mathrm{CO}_{2}$ utilization sinks [135]. In the absence of a ready source of cold energy, electricity demand will typically be double the cooling duty [136]; another thermodynamic disadvantage is the high level of exergy loss due to temperature drop from of combustion products down to cryogenic temperatures [135]. Examples of cryogenic capture techniques include dynamic packed-bed systems [136], mechanical coolers using the Stirling cycle [137] and hybrid membrane/cryogenic process [138]. The latter hybrid process is reported 
to have an energy consumption of $1.7 \mathrm{GJ} / \mathrm{t} \mathrm{CO}_{2}$, which is $50 \%$ lower than that of systems based on Stirling coolers [139].

\subsection{Other $\mathrm{CO}_{2}$ capture systems}

There are also other niche capture options for specific industries. For example, ethanolbased biorefineries produce high-quality $\mathrm{CO}_{2}$ streams that can be readily captured with minimal need for further treatment. This industry represents an attractive and technologically mature capture option. Although its potential scale is ultimately limited in magnitude to approximately a 1:1 mass ratio with ethanol output, it can serve as an initial catalyst for the development of CCUS infrastructure which will be needed as other capture techniques become commercialized [116]. Techno-economic analysis of $\mathrm{CO}_{2}$ capture in bioethanol plants with gas-fired boilers shows that reduction in $\mathrm{CO}_{2}$ can be doubled by integrating $\mathrm{CO}_{2}$ capture from the boiler flue gas, at the expense of a $40 \%$ increase in fossil fuel consumption due to parasitic consumption of the capture system [117]. System-level integration schemes for post-combustion capture may also have significant potential for carbon management. For example, Dean et al. [140] proposed a calcium-looping scheme using calcium oxide $(\mathrm{CaO})$ to simultaneously reduce $\mathrm{CO}_{2}$ emissions from a power plant integrated with a cement plant. Such a scheme can readily be extended to biomass-fired plants to achieve negative emissions.

\subsection{Direct air capture}

Direct air capture (DAC) is an emerging technology which can potentially allow for the development of widely distributed $\mathrm{CO}_{2}$ capture infrastructure. As the term suggests, DAC involves removing $\mathrm{CO}_{2}$ from air through chemical separation processes. Note that this separation needs to occur at thermodynamically unfavourable conditions because of the very dilute ambient levels of $\mathrm{CO}_{2}$ in air, as compared to combustion gases [141]. Pritchard et al. [142] argue that, from a systems perspective, DAC only makes thermodynamic and economic sense after opportunities for $\mathrm{CO}_{2}$ capture from point sources have been maximized. Chen and Tavoni [143] ran global simulations that indicated the need for widespread use of DAC as an important carbon management technology later in the $21^{\text {st }}$ Century. The earliest and most widely studied DAC technique involves the use of aqueous solutions of sodium or calcium hydroxide to skim $\mathrm{CO}_{2}$ from the atmosphere [144]. This reaction forms carbonates which can later be calcined to release a concentrated $\mathrm{CO}_{2}$ stream, while the resulting hydroxide stream recirculates in a closed loop within the system. McLaren [145] rated the technological maturity 
of this DAC technique at 4-6 using the TRL scale, and estimated potential $\mathrm{CO}_{2}$ capture capacity to be $10 \mathrm{Gt} / \mathrm{y}$. House et al. [146] estimate the energy intensity of future large-scale DAC at 400 $\mathrm{kJ} / \mathrm{mol}$ or $9.1 \mathrm{GJ} / \mathrm{t} \mathrm{CO}_{2}$, at a cost of US $\$ 1,000 /$ t. Alternative DAC techniques include those based on bulk solid alkali carbonate systems. The initial work in this area investigated the carbonation of $\mathrm{CaO}$ and $\mathrm{Ca}(\mathrm{OH})_{2}$ at temperatures ranging from 300-450 C; moisture in air was also found to accelerate capture [147]. Sodium-based systems were subsequently reported [148]. Other novel DAC techniques include electrochemical capture, which utilizes hydroxyl ions generated in the electrolysis of water to react with ambient $\mathrm{CO}_{2}$ [149]. The energy consumption reported was $8.7 \mathrm{GJ} / \mathrm{t}$ of $\mathrm{CO}_{2}$, which is $4 \%$ below the benchmark value given by House et al. [146], but which is supplied primarily as electricity.

\subsection{Flexible $\mathrm{CO}_{2}$ Capture}

The energy-intensive nature of most $\mathrm{CO}_{2}$ capture processes results in the potential to use flexible operations as a means to stabilize volatile electricity supply in a grid with high penetration of variable renewable energy. In such systems, $\mathrm{CO}_{2}$ capture can be reduced to free up electric power output that would otherwise be lost to parasitic energy requirements, during periods of high demand or low supply in the grid. They can be used in conjunction with other stabilization strategies such as energy storage or various Power-to-X ( $\mathrm{PtX})$ schemes. A recent review shows that the current literature on such systems focus on amine-based post-combustion capture plants, and that there is significant overall potential to have improved profitability relative to non-flexible capture plants because of the low cost of renewable energy during periods of surplus [150]. The two most common flexible operating schemes in post-combustion capture are bypassing or venting, in which the flue gases bypass the capture system entirely, or solvent storage, in which case the energy-intensive regeneration units are activated only when there is surplus electricity in the grid [151]. Techno-economic analysis by Cohen et al. [152] at carbon prices in the range of US\$20-70/t show that venting-based systems can increase profits relative to inflexible systems by as much as $10 \%$. They also found that solvent storage systems are only viable for periods of up to 30 minutes, beyond which capital costs for storage units become prohibitive. There has been significant interest in developing techniques to enhance capture plant flexibility [150]. Tait et al. [153] reported pilot-scale dynamic tests using synthetic flue gas with $30 \%$ MEA as capture solvent. They determined that response lag was determined mainly by the total inventory of circulating solvent. Fast-response power output maximization schemes they tested were (a) bypassing the capture plant entirely and (b) stopping steam feed into the solvent recovery reboiler. Conversely, ramp-up of steam feed into reboiler was also 
determined to be an effective transient strategy during periods of excess energy availability. In principle, the venting strategy should also be feasible for use in post-combustion $\mathrm{CO}_{2}$ capture using other techniques such as cryogenic or membrane technology.

Although flexible capture systems are often envisioned to compensate for volatility of a renewables-intensive grid at relatively short timescales measured in minutes or hours, they also offer the prospect of risk mitigation for long-term energy deficits. For example, Haszeldine [154] suggested venting as a strategy to free up electricity in a grid with high wind energy penetration, during extended periods of low wind speed. Similar crisis may occur at the seasonal scale, as in the case of droughts reducing hydroelectricity supply over the span of multiple weeks or months. For such long-term variations, other flexible capture schemes based on solvent storage will clearly not be physically viable. Although, as previously noted, the bulk of the literature on flexible $\mathrm{CO}_{2}$ capture deals with post-combustion capture, it is possible to implement approaches to increase the flexibility of systems based on pre-combustion or oxyfuel combustion [155]. These options are shown in Table 2. The prospect for co-generation of secondary products along with electricity is one of the advantageous features of pre-combustion capture systems. Biomass-based IGCC plants co-producing electricity and hydrogen at different ratios were simulated by Cormos et al. [102] using different fuel blends at $\mathrm{CO}_{2}$ capture rates of 92-93\%. A flexible CL-based system for co-production of electricity and hydrogen using methane as fuel was proposed by Ajiwobowo et al. [156]. Their concept combines a solid oxide electrolytic cell (SOEL) with a CLC-CC plant; simulations indicate that a maximum energy efficiency of up to $56 \%$ can be achieved by the system. For cryogenic $\mathrm{CO}_{2}$ capture systems, the product stream can be used as basis for storage of cold energy if there is demand [135]. In addition, the option for intermediate buffer $\mathrm{CO}_{2}$ storage in tanks or naturally occurring geological formations (e.g., caverns) is in principle universally applicable regardless of capture technique, and may play an important role in large-scale CCUS networks where there are also market-based variations in downstream $\mathrm{CO}_{2}$ demand. The potential use of pipelines for interim $\mathrm{CO}_{2}$ storage was recently proposed by Aghajani et al. [157].

In addition, some early work on flexible DAC systems has been reported by Wohland et al. [158]. Their simulations show that negative emissions amounting to $500 \mathrm{Mt} / \mathrm{y}$ can be achieved by running flexible DAC on surplus electricity with high penetration of renewables in the European grid. However, viability requires at least $80 \%$ renewables in power mix. These early results are promising, but further techno-economic assessment is needed to gauge the viability of running flexible large-scale DAC systems at part load for a significant fraction of their operating lives. 
Table 3 Flexibility enhancement techniques for $\mathrm{CO}_{2}$ capture systems, adapted from Domenichini et al. [155]

\begin{tabular}{|l|c|c|c|}
\hline \multicolumn{1}{|c|}{ Technique } & Pre-combustion & $\begin{array}{c}\text { Post- } \\
\text { combustion }\end{array}$ & $\begin{array}{c}\text { Oxy-fuel } \\
\text { combustion }\end{array}$ \\
\hline Storage of $\mathrm{CO}_{2}$ capture solvent & Yes & No & No \\
\hline Storage of liquid $\mathrm{O}_{2}$ & Yes & No & Yes \\
\hline Co-production and storage of $\mathrm{H}_{2}$ & Yes & No & No \\
\hline Switching off capture system & Yes & Yes & No \\
\hline Buffer $\mathrm{CO}_{2}$ storage & Yes & Yes & Yes \\
\hline
\end{tabular}

\section{5. $\mathrm{CO}_{2}$ Utilization Pathways}

$\mathrm{CO}_{2}$ is an important source of carbon for making organic chemicals, materials, and carbohydrates apart from being a greenhouse gas. There have been numerous studies done on $\mathrm{CO}_{2}$ utilisation pathways. One of the pathways that have gained great interest is the utilisation of $\mathrm{CO}_{2}$ in chemical industry via chemical conversion into many useful products by carboxylation and reduction reactions. Besides the utilisation of $\mathrm{CO}_{2}$ in chemical industry, $\mathrm{CO}_{2}$ has also been used in the agriculture sector in China as fertilizer for over 30 years, and have led to marked improvements in plant nutritions. These are among the proof of applications that $\mathrm{CO}_{2}$ utilisation in chemical industry and agricultural sectors are mature technologies. In 2009, electrofuel was introduced and became an emerging technology for $\mathrm{CO}_{2}$ utilization pathway by means of converting $\mathrm{CO}_{2}$ feed stock into synthetic fuel such as methanol, methane, biodiesel and petrol [36]. These three pathways have shown great potential for $\mathrm{CO}_{2}$ emission reduction by transforming it into other useful products, including for clean energy storage.

\subsection{Chemical industry}

There are two common pathways for $\mathrm{CO}_{2}$ utilisation in chemical industry. Due to its inert properties, $\mathrm{CO}_{2}$ could be used as an efficient extractor and solvent [159], or could be directly used for various purposes as been discussed in section 4.1.1.

\subsubsection{Direct utilization based on physico-chemical properties}


$\mathrm{CO}_{2}$ can either be used directly or as a raw material for manufacturing chemical products. Table 1 gives examples of direct uses of $\mathrm{CO}_{2}$. Direct usage of high purity $\mathrm{CO}_{2}$ in either liquid or gaseous form is necessary, especially for applications in the food and beverage industries. Lately, microalgae production has been marked as a potential $\mathrm{CO}_{2}$ sink. The microalgae industry is growing due to products that can be utilized for a wide range of applications [159]. Potential products include pharmaceuticals, human and livestock food, and biofuels [160]. Another interesting and potential utilisation of $\mathrm{CO}_{2}$ is to produce succinic acid [161]. Succinic acid is used as a pH modifier, a flavoring agent and as an anti-microbial agent in the food industry, along with other applications as a detergent/foaming agent, pharmaceutical, chemical intermediate [162].

The food and beverage industries today consume about $11 \mathrm{Mt} \mathrm{CO}_{2}$ annually [163]. The amount of $6 \mathrm{Mt} \mathrm{CO}_{2}$ is used as process gas in various applications such as for industrial gas, and oil and gas recovery (EOR/EGR) [164].

Table 4 Direct usage of $\mathrm{CO}_{2}$

\begin{tabular}{|c|c|c|}
\hline Application & Description & References \\
\hline Solvent & $\begin{array}{l}\text { - Solvent for chemical reactions and process } \\
\text { - Results in more efficient process than conventional } \\
\text { solvent } \\
\text { - Quick development from supercritical dissolvable with } \\
\text { non-dissolvable process } \\
\text { - Miscibility or solubility switch } \\
\text { - Mobile phase in continuous flow catalyst for a new } \\
\text { chemical synthesis initiative. }\end{array}$ & [165] \\
\hline Refrigerant & $\begin{array}{l}\text { - The old version of refrigerant that have been used before } \\
\text { - Have been displaced with synthetic refrigerant due to } \\
\text { high pressure needed for } \mathrm{CO}_{2} \text { refrigerant } \\
\text { - Natural and safer refrigerant compared to synthetic } \\
\text { refrigerant }\end{array}$ & [165] \\
\hline $\begin{array}{l}\text { Protecting } \\
\text { gas }\end{array}$ & $\begin{array}{l}\text { - Exploitation of non-oxidizing and inert properties of } \mathrm{CO}_{2} \\
\text { - Use in fire extinguisher and safety special equipment } \\
\text { - Exhibits high } \mathrm{CO}_{2} \text { concentration atmosphere in museum }\end{array}$ & [165] \\
\hline
\end{tabular}




\begin{tabular}{|c|c|c|}
\hline & $\begin{array}{l}\text { - To preserve paper of historical manuscript from } \\
\text { acidification that could cause mechanical degradation. }\end{array}$ & \\
\hline $\begin{array}{l}\text { Enhanced oil } \\
\text { and gas } \\
\text { recovery }\end{array}$ & $\begin{array}{l}\text { - Largest direct } \mathrm{CO}_{2} \text { application that have been used since } \\
1980 \\
\text { - economically attractive } \\
\text { - enhance oil recovery up to } 15 \% \text { for each reservoir } \\
\text { - mature technology for EOR but not mature for enhanced } \\
\text { gas recovery (EGR) }\end{array}$ & [166] \\
\hline $\begin{array}{l}\text { Cleaning and } \\
\text { extracting } \\
\text { agents }\end{array}$ & $\begin{array}{l}\text { - supercritical carbon dioxide extraction } \\
\text { - Extracted product residues freed from undesired } \\
\text { substance } \\
\text { - Non-polar impurities cleaning agent } \\
\text { - Dry cleaning agent in archaeology and arts } \\
\text { - Separation of heavy metal in wastewater treatment using } \\
\text { nuclear technology }\end{array}$ & [166] \\
\hline $\begin{array}{l}\text { Enhanced } \\
\text { coal bed } \\
\text { methane }\end{array}$ & - Assist trapped methane extraction & [166] \\
\hline $\begin{array}{l}\text { Techniques } \\
\text { for reversible } \\
\text { adsorption } \\
\text { and } \\
\text { assimilation } \\
\text { of carbon } \\
\text { dioxide }\end{array}$ & $\begin{array}{l}\text { - Could absorb } \mathrm{CO}_{2} \text { using reversible amine solution } \\
\text { technology } \\
\text { - Could also use membrane resins and inorganic systems }\end{array}$ & {$[166]$} \\
\hline $\begin{array}{l}\text { Impregnating } \\
\text { operator }\end{array}$ & $\begin{array}{l}\text { - Invert procedure of extraction } \\
\text { - Impregnation of a framework with low sub-atomic } \\
\text { weight mixes } \\
\text { - Improved the heat and mechanical stabilities of polymer } \\
\text { and polymeric membranes }\end{array}$ & [165] \\
\hline $\begin{array}{l}\text { Acidity } \\
\text { controller for }\end{array}$ & $\begin{array}{l}\text { - Acidity or } \mathrm{pH} \text { adjuster } \\
\text { - Neutralization agent for waste waters from steel industry }\end{array}$ & [165] \\
\hline
\end{tabular}




\begin{tabular}{|c|c|c|}
\hline $\begin{array}{l}\text { aqueous } \\
\text { solution }\end{array}$ & & \\
\hline $\begin{array}{l}\text { Use in food } \\
\text { and beverage } \\
\text { industries }\end{array}$ & $\begin{array}{l}\text { - Used to carbonize beverages } \\
\text { - To produce deoxygenated water } \\
\text { - Casein precipitation } \\
\text { - Pre-treatment of olives before oil pressing } \\
\text { - Used as acidifier } \\
\text { - Need very high purity of } \mathrm{CO}_{2} \\
\text { - Enhance the shelf-life, aroma and vitamin retentions of } \\
\text { fruits and vegetable by using } \mathrm{CO}_{2} \text { controlled atmosphere } \\
\text { storage of fruits and vegetables }\end{array}$ & [166] \\
\hline
\end{tabular}

Another potential application is the use of $\mathrm{CO}_{2}$ as a commercial refrigerant. Selection of the refrigerant strongly depends on the system requirements which need to be fulfilled. It should be noted that its critical unique point is at $31^{\circ} \mathrm{C}$ and 74 bar. Usage of $\mathrm{CO}_{2}$ as a refrigerant implies dealing with pressures up to 10 times higher compared to the commercial hydrofluorocarbons [167]. Because the Global Warming Potential (GWP) of $\mathrm{CO}_{2}$ is several orders of magnitude lower of some commercial hydrofluorocarbons utilized today (see Table 4), climate implications of leaks and fugitive emissions are significantly reduced.

Table 5 Characteristics of the most prominent refrigerators which are in use today and will be dominant in the short term [167]

\begin{tabular}{|l|c|c|c|c|c|c|c|c|c|c|}
\hline Refrigerant & R717 & R744 & R290 & R600a & R22 & R134a & R410A & R32 & R404a & R1234ze \\
\hline Group & Inorganic & $\mathrm{CO}_{2}$ & HC & HC & HCFC & HFC & HFC & HFC & HFC & HFC \\
\hline ODP & 0 & 0 & 0 & 0 & 0.055 & 0 & 0 & 0 & 0 & 0 \\
\hline GWP100 & 0 & 1 & 3 & 3 & 1700 & 1430 & 1980 & 675 & 3922 & 6 \\
\hline $\begin{array}{l}\text { Atmospheric } \\
\text { lifetime } \\
\text { (years) }\end{array}$ & Few days & $\begin{array}{c}\text { Few } \\
\text { days }\end{array}$ & $\begin{array}{c}\text { Few } \\
\text { days }\end{array}$ & $\begin{array}{c}\text { Few } \\
\text { days }\end{array}$ & $1-20$ & $1-300$ & & $4-5$ & & - \\
\hline
\end{tabular}

In refrigerant applications, the liquid density of $\mathrm{CO}_{2}$ is lower than that of other alternatives; hence, requirements for system design and size are lower as well [168]. Refrigeration capacity of $\mathrm{CO}_{2}$ is around $22600 \mathrm{~kJ} / \mathrm{kg}$ at $0^{\circ} \mathrm{C}$, which is $5-22$ times higher than those of commercial synthetic refrigerants. In addition, $\mathrm{CO}_{2}$ has a small decline of saturation 
temperature relative to pressure drop, which enhance mass flux in evaporator and suction pipes. This feature is especially pronounced in temperature range of -30 to $-50{ }^{\circ} \mathrm{C}$, where higher system efficiencies have been noted [169]. Sharma et al. [170] found that the implementation of $\mathrm{CO}_{2}$ transcritical booster systems or cascade/secondary loop systems in supermarkets using optimized operating conditions lead to reduced direct GHG emissions while achieving comparable energy consumption. Abas at el. [169] stated that when $\mathrm{CO}_{2}$ is used as a refrigerant for the supermarket systems, the coefficient of performance (COP) is often higher than those of $\mathrm{HFC}$ based systems. $\mathrm{CO}_{2}$ is also one of the most popular natural refrigerant for ground source heat pumps [171]. Additional work on its utilization in such applications have been reported using carbon dioxide direct-expansion ground source heat pump ( $\left.\mathrm{CO}_{2}-\mathrm{DX}-\mathrm{GSHP}\right)$ [172], carbon dioxide direct-expansion geothermal heat pump [173], transcritical $\mathrm{CO}_{2}$ heat pump integrated with thermal energy storage [174], geothermal heat pump working with different zeotropic and azeotropic mixtures [175]. Wang et al. [176] investigated a novel $\mathrm{CO}_{2}$ heat pump system with Series Gas Cooler (SGC) for the application in an electrical vehicle (EV). System using $\mathrm{CO}_{2}$ as a refrigerant, offers a great heating advantages in a cold climate. At the temperature of $-20{ }^{\circ} \mathrm{C}$, the proposed heat pump system achieved $5.6 \mathrm{~kW}$ maximum heating capacity and 1.8 COP, which greatly outperforms the conventional PTC heating supplement for an EV.

\subsubsection{Chemical conversion of $\mathrm{CO}_{2}$}

Chemical conversion of $\mathrm{CO}_{2}$ can be classified into two main types of reaction, namely, carboxylation and reduction. Aresta and Dinbenedetto [166] reported that $110 \mathrm{Mt} \mathrm{CO}_{2}$ per year have been either converted into chemicals such as urea (70 $\mathrm{Mt} \mathrm{CO}_{2}$ per year), inorganic carbonates (30 $\mathrm{Mt} \mathrm{CO}_{2}$ per year) and pigment or additives to methanol synthesis $\left(6 \mathrm{Mt} \mathrm{CO}_{2}\right.$ per year). The amount of $20 \mathrm{kt} \mathrm{CO}_{2}$ per year has been used to produce salicylic acid together with the production of a few kt per year of propylene carbonate as side products [177]. Additionally, $18 \mathrm{Mt}$ of $\mathrm{CO}_{2}$ per year has been used as a fluid that can transmit energy, via a process that involves adjustment of the fluid pressure [11].

\subsubsection{Carboxylation}

Carboxylation involves $\mathrm{CO}_{2}$ reaction that occurs without breaking the carbonyl $(\mathrm{C}=\mathrm{O})$ bonds completely. This category of reaction includes mineral carbonation, use of $\mathrm{CO}_{2}$ as initiator of some carbon-based chemicals, and polymer production [177]. The ecological advantages of carboxylation include the substitution of vitality, outflows of harmful reactants 
(e.g. epoxides), and long term carbon storage [178]. Table 5 presents the chemicals and final products produced from carboxylation reaction of $\mathrm{CO}_{2}$.

Table 6 Products obtained from carboxylation reaction of $\mathrm{CO}_{2}$

\begin{tabular}{|c|c|}
\hline & Application \\
\hline Urea & $\begin{array}{l}\text { Fertilizer } \\
\text { Polymer synthesis (melamine and urea- } \\
\text { formaldehyde resins) } \\
\text { deNOx application for diesel-engine vehicles }\end{array}$ \\
\hline $\begin{array}{l}\text { Acrylates, lactones and carboxylic } \\
\text { acids }\end{array}$ & $\begin{array}{l}\text { Super absorbents used in diapers (acrylates) } \\
\text { Solvent, pharmaceuticals, } \\
\text { surfactants, cosmetic (carboxylic acids) } \\
\text { Fragrance (lactones) }\end{array}$ \\
\hline Monomeric carbonate & Alternative to toxic phosgene \\
\hline Isocyanate & Sealants and adhesives \\
\hline \multicolumn{2}{|l|}{ Polymeric material } \\
\hline Polycarbonate & $\begin{array}{l}\text { Phosgene-free process to aromatic polycarbonates } \\
\text { (APCs) } \\
\text { Ethylene carbonate }\end{array}$ \\
\hline Polyolefin & Polypropylene and polyethylene carbonate \\
\hline Polyhydroxyalkanoate & $\begin{array}{l}\text { Biodegradable resins } \\
\text { Bioplastic }\end{array}$ \\
\hline Polyether carbonate polyols & $\begin{array}{l}\text { Polyurethane, elastomers, coatings, sealants and } \\
\text { adhesives }\end{array}$ \\
\hline Chlorinated polypropylene & Degradable $\mathrm{CO}_{2}$ copolymer \\
\hline
\end{tabular}

\subsubsection{2 $\mathrm{CO}_{2}$ reduction reaction}

In the $\mathrm{CO}_{2}$ reduction reaction, one or both carbonyl $(\mathrm{C}=\mathrm{O})$ bonds are broken during the product formation [179]. The products include methane, methanol, ethanol, carbon monoxide, synthetic gas, formic acids and acetone. The $\mathrm{CO}_{2}$ reduction reaction is energy-intensive because it needs a large amount of energy to break the bonds [180]. The required energy can be provided by high-energetic reactants such as hydrogen, by heat [181], electricity [182], sunlight [183] or microwaves [184]. 
Table 7 Reduction reaction of $\mathrm{CO}_{2}$

\begin{tabular}{|c|c|c|c|}
\hline Routes & $\begin{array}{l}\text { Method / } \\
\text { reaction }\end{array}$ & Product & Descriptions \\
\hline \multirow[t]{4}{*}{ Chemical } & $\begin{array}{l}\text { Fischer } \\
\text { Tropsch }\end{array}$ & $\begin{array}{l}\text { Methanol, } \\
\text { hydrocarbon }\end{array}$ & $\begin{array}{l}\text { Reversible Fischer Tropsch process } \\
\text { to reduce } \mathrm{CO}_{2} \text { to methanol and } \\
\text { hydrocarbon }[165]\end{array}$ \\
\hline & Dry reforming & $\mathrm{CO}, \mathrm{H}_{2}$ & $\begin{array}{l}\text { Reversible drying reforming step to } \\
\text { produce } \mathrm{CO} \text { and } \mathrm{H}_{2}[184]\end{array}$ \\
\hline & $\begin{array}{l}\text { Reverse water } \\
\text { gas shift }\end{array}$ & $\mathrm{CO}, \mathrm{CH}_{4}$ & $\begin{array}{l}\text { Reverse water gas shift reaction to } \\
\text { produce } \mathrm{CO} \text { and } \mathrm{CH}_{4}[165]\end{array}$ \\
\hline & $\begin{array}{l}\text { Sabatier } \\
\text { reaction }\end{array}$ & Methane & $\begin{array}{l}\text { Sabatier reaction for methane } \\
\text { production }[165]\end{array}$ \\
\hline \multirow[t]{3}{*}{ Electrochemical } & \multicolumn{3}{|c|}{ Solid oxide fuel cell } \\
\hline & Platinum & $\mathrm{CO}$ & $\begin{array}{l}\text { - Initially proposed to produce } \mathrm{O} 2 \\
\text { from CO2 rich atmosphere [185] } \\
\text { - Extended research to identify the Pt } \\
\text { stable oxide [186] } \\
\text { - The performance have been } \\
\text { improved when gas diffusion was } \\
\text { found out to be the limiting factor } \\
\text { [187] } \\
\text { The improvement of efficiency } \\
\text { using Pt-YSZ cermet electrode } \\
\text { [188]. }\end{array}$ \\
\hline & Nickel & $\mathrm{CO}$, methane & $\begin{array}{l}\text { - Nickel-YSZ electrode[189], } \\
\text { - Electrocatalytic dry reforming } \\
\text { process [190] } \\
\text { - Nickel cermet (Ni-YSZ-CeO) } \\
\text { electrode [191] } \\
\text { Electrolyser mode at high } \\
\text { temperature [192] }\end{array}$ \\
\hline
\end{tabular}




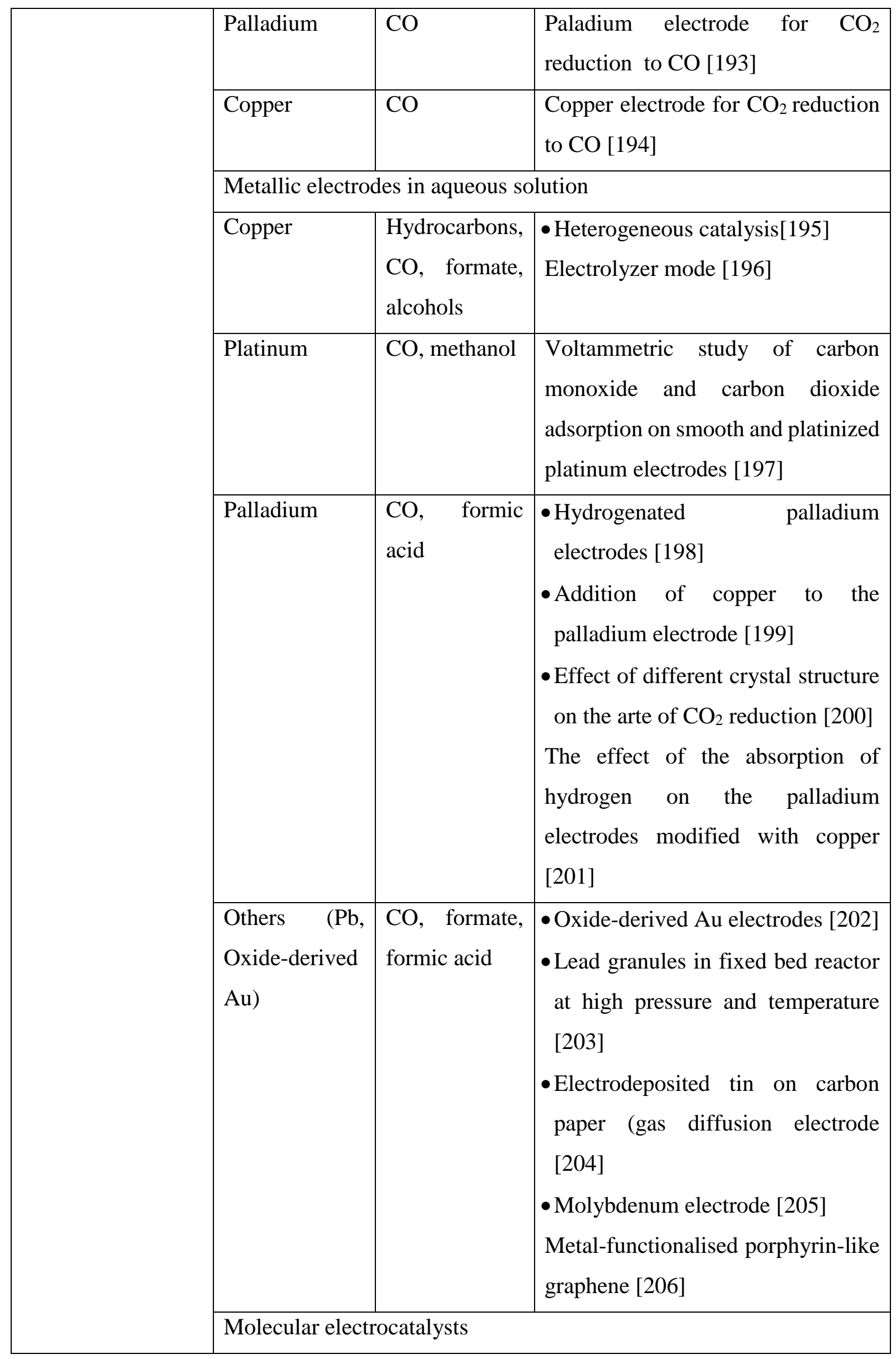




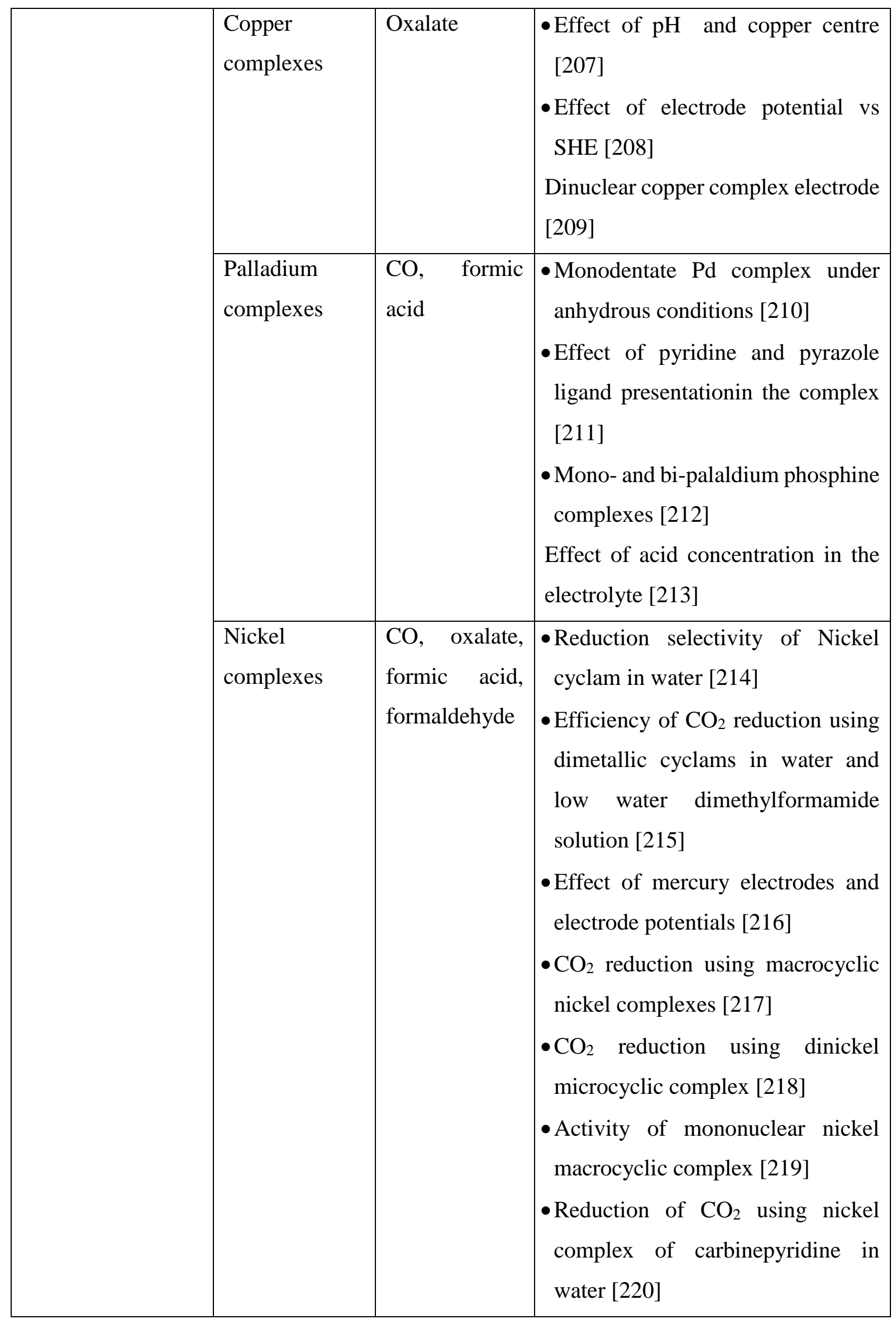




\begin{tabular}{|c|c|c|c|}
\hline & & & $\begin{array}{l}\text { Electroreduction using Ni-tetra- } \\
\text { phthalocyanine for formic acid and } \\
\text { formaldehyde production [221] }\end{array}$ \\
\hline & $\begin{array}{l}\text { Cobalt } \\
\text { complexes }\end{array}$ & $\begin{array}{l}\mathrm{CO} \text { formic } \\
\text { acid, alcohols } \\
\text { (methanol, } \\
\text { ethanol), } \\
\text { acetone }\end{array}$ & $\begin{array}{l}- \text { Reduction potentials of } \mathrm{CO}_{2} \text { based } \\
\text { on type of ligands of terdentate } \\
\text { cobalt complexes in DMF [222] } \\
\text { - Immobilisation of the cobalt } \\
\text { complexes to dual -film electrode } \\
\text { at low potential under ambient } \\
\text { aqueous [223] } \\
\text { Macrocyclic cobalt complexes in } \\
\text { aqueous solution [224] }\end{array}$ \\
\hline & Pyridinium & $\begin{array}{l}\text { Methanol, } \\
\text { formaldehyde, } \\
\text { fromic acid }\end{array}$ & $\begin{array}{l}\text { A new homogeneous electrocatalyst } \\
\text { for the reduction of carbon dioxide } \\
\text { to methanol at low overpotential } \\
\text { [225] }\end{array}$ \\
\hline \multirow[t]{5}{*}{ Photochemical } & $\begin{array}{l}\text { Transition } \\
\text { metal complex }\end{array}$ & $\begin{array}{l}\mathrm{CH}_{2} \mathrm{OH}, \mathrm{CO}, \\
\mathrm{CH}_{2} \mathrm{O}, \\
\mathrm{CH}_{3} \mathrm{OH}, \mathrm{CH}_{4}\end{array}$ & $\begin{array}{l}\text { Transition metal complex } \\
\text { photochemical study [226] }\end{array}$ \\
\hline & Cascade metal & Methanol & $\begin{array}{l}\text { Novel conversion of carbon dioxide } \\
\text { to methanol catalyzed by sol-gel } \\
\text { immobilized dehydrogenases [227] }\end{array}$ \\
\hline & Semiconductor & $\begin{array}{l}\mathrm{CO}, \text { formate, } \\
\text { formadehyde, } \\
\text { methanol }\end{array}$ & $\begin{array}{l}\text { Photoelectrochemical reduction of } \\
\text { carbon dioxide using polyaniline- } \\
\text { coated silicon [228] }\end{array}$ \\
\hline & $\begin{array}{l}\text { Metallic } \\
\text { molecular } \\
\text { catalyst }\end{array}$ & $\begin{array}{l}\mathrm{CO}, \text { formate, } \\
\text { formadehyde, } \\
\text { methanol }\end{array}$ & $\begin{array}{l}\text { Electrochemistry of } \\
\text { tetraaeomacrocyclic metal } \\
\text { complexes at illuminated p-type } \\
\text { silicon semiconducting electrodes } \\
{[229]}\end{array}$ \\
\hline & $\begin{array}{l}\text { Non-metallic } \\
\text { molecular } \\
\text { catalyst }\end{array}$ & $\begin{array}{l}\mathrm{CO} \text {, formate, } \\
\text { formadehyde, } \\
\text { methanol }\end{array}$ & $\begin{array}{l}\text { Photoelectrochemical pumping of } \\
\text { enzymatic } \mathrm{CO}_{2} \text { reduction [230] }\end{array}$ \\
\hline
\end{tabular}




\begin{tabular}{|c|c|c|c|}
\hline \multirow[t]{2}{*}{ Bioelectrochemical } & $\begin{array}{l}\text { Microbial fuel } \\
\text { cell with } \\
\text { microbial } \\
\text { electrolysis } \\
\text { cell }\end{array}$ & Formic acid & $\begin{array}{l}\text { Electrochemical reduction of carbon } \\
\text { dioxide in an MFC-MEC system } \\
\text { [231] }\end{array}$ \\
\hline & $\begin{array}{l}\text { Stainless steel } \\
\text { electrode with } \\
\text { bacteria }\end{array}$ & Glycerol & $\begin{array}{l}\text { Electrochemical reduction of } \mathrm{CO}_{2} \\
\text { catalysed by Geobacter sulphur } \\
\text { reducens grown on polarized } \\
\text { stainless steel cathodes [232] }\end{array}$ \\
\hline
\end{tabular}

\subsubsection{Sources and purity of $\mathrm{CO}_{2}$}

Sources of $\mathrm{CO}_{2}$ can be classified into two categories, namely, $\mathrm{CO}_{2}$ captured from the atmosphere and $\mathrm{CO}_{2}$ captured from point sources. $\mathrm{CO}_{2}$ can be removed from the atmosphere using the DAC technology [233]. Due to the low concentration of $\mathrm{CO}_{2}$ in the air, the specific energy requirement for its recovery is very high, making DAC less attractive compared to $\mathrm{CO}_{2}$ capture from point sources [233].

$\mathrm{CO}_{2}$ point sources include numerous industries such as fermentation-based processes, cement production, and fertilizer manufacturing [165]. High purity $\mathrm{CO}_{2}$ captured is usually obtained from chemical industries and refineries [234]. $120 \mathrm{Mt}$ per year of pure $\mathrm{CO}_{2}$ are separated during the production of $\mathrm{H}_{2} / \mathrm{N}_{2}$ gas mixture for ammonia synthesis [165]. The purity of $\mathrm{CO}_{2}$ captured from ammonia production and fermentation is practically suitable to be used for all synthesis purposes [235]. The sources of captured $\mathrm{CO}_{2}$ can be matched with suitable applications (demands) depending on its purity requirements [165]. For example, captured $\mathrm{CO}_{2}$ from ammonia plant has been paired with urea production, while $\mathrm{CO}_{2}$ captured from fermentation has been paired with beverage industry.

$\mathrm{CO}_{2}$ captured from power plants flue gas is considered to be a major potential source at the global scale [178]. Fossil-fuel power plants release approximately $78 \%$ of all $\mathrm{CO}_{2}$ from point sources [178]. The capture of carbon dioxide from the flue gas of coal, oil, or gas-fired power plants, and from industrial processes is a mature and commercially available technology [166]. However, the $\mathrm{CO}_{2}$ captured from power plant flue gases needs to be purified prior to use, due to the potential presence of impurities such as $\mathrm{O}_{2}, \mathrm{~N}_{2}, \mathrm{H}_{2} \mathrm{O}, \mathrm{H}_{2} \mathrm{~S}, \mathrm{CO}, \mathrm{CO}_{2}, \mathrm{SO}_{3}, \mathrm{NO}_{\mathrm{X}}$, heavy metals (e.g., $\mathrm{Hg}$ ), and trace hydrocarbons. Certain flue gas impurities may act as catalyst poison [165]. Screening criteria should be considered when using $\mathrm{CO}_{2}$ from power plant flue 
gas for chemical synthesis applications involving modern catalyst; for example, in the case of methanol synthesis, $\mathrm{H}_{2} \mathrm{~S}$ content in the feed gas has to be less than $0.1 \mathrm{ppm}$ [236].

The quality of captured $\mathrm{CO}_{2}$ that is distributed via pipeline is usually suitable to be used as raw material for chemical reactions. The type of contaminant and purity of $\mathrm{CO}_{2}$ may be relevant depending on the application. Very high $\mathrm{CO}_{2}$ quality levels are required in food, beverage and pharmaceutical industry [237]. For example, high purity requirements are stipulated for the licensing of pharmaceutical ingredients such as salicylic acid [165]. For chemical products, heavy metal impurities need to be low, for example when $\mathrm{CO}_{2}$ is converted to urea used as fertilizers [165]. On the other hand, $\mathrm{CO}_{2}$ purity may be less critical in cases where final product refining or purification follows the incorporation of $\mathrm{CO}_{2}$.

Ammonia production has been recognized as one of the $\mathrm{CO}_{2}$ point sources with lower energy requirement, providing $127 \mathrm{Mt}$ per year $\mathrm{CO}_{2}$ as a co-product [166]. Compared to ammonia production, $\mathrm{CO}_{2}$ recovery from fossil-fuel power plant requires more energy [238]. Other sources of $\mathrm{CO}_{2}$ can be obtained from manufacture of ethylene oxide, bioethanol, iron and steel, cement, pulp and paper industry, refineries as well as in sweetening of sour natural gas [250].

\subsection{Use of $\mathrm{CO}_{2}$ in Agriculture}

$\mathrm{CO}_{2}$ can be used in directly gaseous form as a greenhouse fertilizer, stimulating plant growth without requiring more chemical fertilizer input. $\mathrm{CO}_{2}$ fertilizer have been used since 30 years ago in China [239]. Research shows that $\mathrm{CO}_{2}$ gaseous fertilizers could increase crop yield by $33.31 \%$ and accelerate crop growth [239]. Similar findings have been reported by the National Assessment Report of Carbon Utilization Technologies (CUTs) [240]. Other findings have also shown that, $\mathrm{CO}_{2}$ gas fertilizer could increase the water use efficiencies by reducing evaporation losses during crop transpiration and photosynthesis [241]. For example, this effect has been observed in high latitude wheat plantations in the United State and Canada, with wheat production increasing by $10 \%$ and corresponding reduced water consumption [242]. Increased carbon dioxide in wheat plantation in arid climates resulted in $8 \%$ gain in wheat production and improved crop water productivity by up to $50 \%$ [243]. Without $\mathrm{CO}_{2}$ boost, $29 \%$ of yield reduction has been reported due to the lack of rain in unirrigated wheat crop.

$\mathrm{CO}_{2}$ can be captured in algal systems to produce algal-bio-fertilizer, which can then be used to improve rice quality while simultaneously increasing its yield [244]. From a climate standpoint, this alternative is more environmental friendly as compared to synthetic chemical 
fertilizers. Among various $\mathrm{CO}_{2}$ utilization technologies in multiple field trials, algal fertilizer has shown the highest efficacy and greatest emissions reduction [245]. On the other hand, Zhao et al. [246] found that, increasing $\mathrm{CO}_{2}$ pressure can result in faster conversion of waste phosphogypsum into ammonia sulfate, which can in turn be used to produce fertilizers for the agriculture sector. This approach not only reduces the environmental impact of the large amount of waste phosphogypsum every year, but also sequesters captured $\mathrm{CO}_{2}$.

The integration of chemicals and energy production in large-scale industrial algal biofarms has led to the "algal biorefinery" concept. The main advantage of this process is the large intake or consumption of $\mathrm{CO}_{2}$ for algal biomass production, since production 1 ton of dry algal biomass production requires about 1.8 tons of $\mathrm{CO}_{2}$ [179]. Potential products from algal biorefinery include bioenergy, carbohydrate, protein extract and some organic chemical for cosmetic, pharmaceutical and nutraceutical industries. Apart from algae, some microorganisms such as such as Escherichia coli $\left(E\right.$. coli) could produce succinic acid from indirect $\mathrm{CO}_{2}$ transformation with glucose from wheat or unrefined sugar. Many ventures have been being established around biosuccinic acid production, as summarized in Table 8.

Table 8 Companies involved in biosuccinic production [179]

\begin{tabular}{|l|l|l|}
\hline Company's name & Location & Production \\
\hline Bioamber (joint DNP Green and ARD) & Pomacle, France & $2 \mathrm{kta}^{-1}$ \\
\hline DSM and Roquette Freres & Lestrem, France & $2 \mathrm{kta}^{-1}$ \\
\hline Myriant & Louisiana, USA & $20 \mathrm{kta}^{-1}$ \\
\hline BASF and CSM & Purac, Spain & \\
\hline
\end{tabular}

Another agricultural-biological routes of utilizing $\mathrm{CO}_{2}$ is the photosynthetic approach to grow palisade layer plant cell culture to produce low cost sugars (glucose and sucrose). This process has been patented and commercialized by Naturally Scientific, a company that has been producing both sugars and oils in their demonstration plant located in Nottingham, UK since 2013 [179].

\subsection{Electrofuels - Chemical Storage Technologies}

Chemical storage of variable electricity is an important part of the future energy systems, as it both improves the system flexibility while producing fuels for transport or chemical industry [36]. Excess electricity can be utilized to produce these commodities as a 
form of indirect energy storage. Electrofuels are produced by merging carbon source and electrolytic hydrogen in so-called xTE processes [37] (see Figure 5). Carbon sources can be derived by either point source carbon capture or DAC, biomass gasification, or biogas. Combustion of the resulting electrofuel does emit net $\mathrm{CO}_{2}$ emissions if only renewable electricity is used as input [247]. These fuels can minimize the use of biomass if biogenic $\mathrm{CO}_{2}$ is used [248]. If $\mathrm{CO}_{2}$ from DAC is used, these fuels offer the closed-loop carbon cycling [249]. Carbon capture and utilisation of $\mathrm{CO}_{2}$ emissions for production of low carbon fuels represent the biggest market for CCU technology, as there is a need for fossil carbon source substitute $[8]$.

A range of products can be obtained making these processes flexible and applicable for different purposes from transport fuels to ammonia for industrial purposes. The most commonly suggested fuels are methane, methanol and DME, but there is an option to produce e-petrol or e-diesel via Fisher-Tropsch synthesis. A recent review of the literature on this topic [250] gives an overview of the production costs of electrofuels ranging from $160-210 €_{2015} / \mathrm{MWh}$ fuel in 2030. An increasing number of studies have presented different pathways to produce electrofuels and investigated their feasibility and potential [251] indicating that the costs of renewable energy systems with electrofuels are not more expensive than business as usual (BAU) fossil fuels systems. Goldmann et al. [72] studied the potential of electrofuels as aviation fuels, with emphasis on their compatibility with current aircraft engines. Bongartz et al. [252] investigated and compared different transportation fuels produced from renewable hydrogen and green carbon dioxide for light-duty vehicles. Blanco et al. [253] made a cost optimization study for hydrogen and Power-to-Liquid in the EU energy system. The EU energy transition to a RES based energy system and the role of Power-to-Methane has been investigated in [254]. The role of Power-to-Liquid and Power-to-Gas in the future German energy system has been discussed in [255]. Hansson et al. [256] has looked into potential of CCU based electrofuels for Sweden, and found that the potential for electrofuels is limited by electricity demand rather than the required $\mathrm{CO}_{2}$ missions cuts. Other papers looked into feasibility of using electrofuels in Germany [257]. Koytsoumpa et al. [258] investigated the emission-to-liquid concept in steel and power industry. 


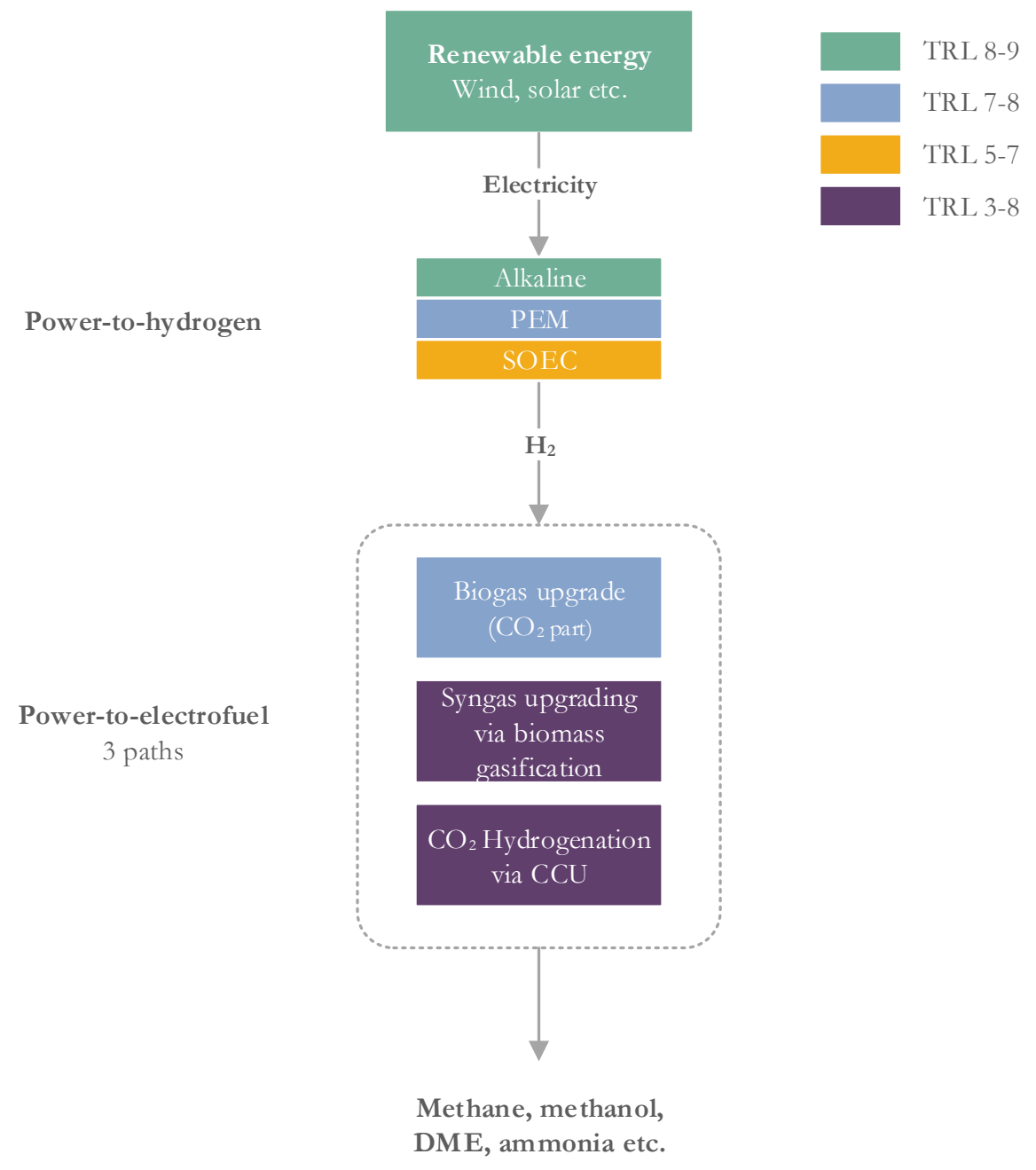

Figure 5. Electrofuel production concepts and technology readiness levels, adapted from [259]

Production of electrofuels not only depends on the TRL of CCU, but also the TRL of water and steam electrolysis. Low temperature alkaline electrolysis is the only commercially available technology, but for purposes of supporting flexible systems, has the disadvantage of slow dynamic response [260]. The use of polymer electrolyte membrane (PEM) electrolysis has been emerging in the last decade [261], with main challenge being the reduction of requirement for scarce noble metals [262]. Solid Oxide Electrolysis cell (SOEC) is a promising future technology with low costs and high efficiency (up to $80 \%$ LHV) [96]. It has been demonstrated on the small scale and has promising response rates, but still has issues with cell durability [263]. A recent review of cost trends from the 1990s to 2017 on electrolysis costs [264] shows a significant drop in costs for future projections as a result of a learning rates. Alkaline electrolysis is still the cheapest technology currently available with costs ranging between 600$2600 €_{2015} / \mathrm{kW}_{\mathrm{el}}$ while PEM has range between $1900-3700 €_{2015} / \mathrm{kW}_{\mathrm{el}}$, for the future projections 
(2030) SOEC has cheapest costs ranging between $400-1000 €_{2015} / \mathrm{kW}_{\mathrm{el}}$ followed by alkaline $400-900 €_{2015} / \mathrm{kW}_{\mathrm{el}}$ and PEM $300-1300 €_{2015} / \mathrm{kW}_{\mathrm{el}}[250]$.

During the last decade, several demonstration plants have been built and operated [265]. The implementation of $\mathrm{PtX}$ technologies has peaked in 2018, with 18 projects currently running with Germany having highest share of the projects [261]. However, most of the projects are are limited to production of hydrogen, and only few demonstration projects with CCU have been implemented. Two demonstration projects have been reported on methanol production in Iceland [266] and Sunfire e-crude production in Dresden [267], both based on use of $\mathrm{CO}_{2}$. $\mathrm{MefCO}_{2}$ project [268] aims to demonstrate production of methanol from captured $\mathrm{CO}_{2}$ from power plant and electrolytic hydrogen produced from surplus renewable electricity. In FReSMe project the aim is to demonstrate capturing the $\mathrm{CO}_{2}$ from steel industry and producing methanol with electrolytic hydrogen [269]. Sunfire is planning to build another facility in Norway with capacity of 8,000 t/year starting in 2020 [270].

\section{Integration of Energy Systems and Carbon Capture}

Future energy demands can potentially be met with $100 \%$ renewables provided that they are conceptualized and planned using a system-level integrated approach [36]. Use of CCU technologies in the future energy system could play an important role as it can help to increase the flexibility of renewable energy systems by indirectly storing variable electricity into a wide range of fuels and chemicals. In a recent report, the European Commission acknowledged that the CCS's role could only be in the short/medium term for industrial processes, and to generate net-negative emissions from biomass combustion [271]. Krey et al [272] looked into different pathways with and without CCS and concluded that the combination of bioenergy coupled with CCS makes the most sense in terms of emission reductions. Integrated value chains of CCU can help the integration of technology with energy system [10] and support better the integration of renewable energy with different end-use products. Carbon capture from more distributed generation systems in the future will not necessarily prove infeasible, especially in the case that the transportation and storage demand is minimized [273].

Two carbon capture (CC) technologies are particularly interesting for integration with energy systems; post-combustion and pre-combustion $\mathrm{CC}$ technology. As pre-combustion $\mathrm{CC}$ technology includes gasification process of the fuel, there is a demand for electricity for the

gasification process. For example, a $300 \mathrm{MW}$ integrated combined cycle gasification plant requires between 36.5-38 MW of power for the gasification process [274]. Gasification process 
can be run flexibly, and does not need to match the exact timing of the power plant electricity generation, which could be beneficial for balancing the supply and demand on the power grid. On the other hand, the post-combustion capture removes $\mathrm{CO}_{2}$ from flue gases, after combustion occurred, and is more mature and established technology.

The total energy penalty is more significant in the case of pre-combustion capture than in the case of post-combustion capture, as it amounts to $28.4 \%$ in the case of a typical coal-fired plant and $25.3 \%$ in the case of gas-fired power plant; by comparison, the typical energy penalty for post-combustion capture is $21 \%$ in the case of coal-fired power plant, and $14.7 \%$ in the case of gas-fired plant for post-combustion CC [275]. Another paper reports that the energy penalty in the case of coal plant post-combustion removal has a theoretic minimum of $11 \%$, energy penalty of $40 \%$ is easily achievable, while $29 \%$ of energy penalty is a reasonable target [276]. A recent literature review on the efficiency penalty for different types of plants with $\mathrm{CC}$ found that most of the power plants have efficiency penalty of around 10 percentage points, independent on the fuel type [277]. This energy penalty can provide the basis for modulating power plant output to help balance supply and demand in the grid.

Nord and Bolland [278] simulated plant flexibility of pre-combustion capture and showed good operation and wide load range in their results. According to Abdilahi et al [279], carbon capture can increase the flexibility of the existing power plants due to the controllability of its operations related to the transport and storage of the $\mathrm{CO}_{2}$. Flexible carbon capture can improve the investment value by allowing for a temporary increase in electrical output that can help in relation to grid reliability [280]. Power plants with CC can be operated as load following plants in systems with high penetration of renewables, and analysis shows that bidding into intraday electricity market has the highest potential [281]. Tait et al [153] reported no significant barriers for flexible operation of post-combustion capture pilot plant. Nevertheless, while the plant is operating at part load, the $\mathrm{CO}_{2}$ content of the flue gases decreases. CCS plant operators would prefer to run it as a base load in order to save on operating costs [282].

Some authors have dealt with the integration of CCS into energy planning. One of the papers integrated CCS into EFOM model, a linear optimization energy model [283]. Their model showed that for the case of South Korea traditional fossil fuel plants would start investing in CCS at an emission price of $40 \mathrm{USD} /$ tonne of $\mathrm{CO}_{2}$ [283]. However, wind energy would be cheaper than the combination of traditional fossil fuel plant combined with CCS storage [283]. Another paper focused on operational optimization of an energy system [284]. The authors claimed that integration of fossil power plants with $\mathrm{CO}_{2}$ capture with renewable energy in the system, increased the flexibility of the energy system and reduced operating costs for $20 \%$ 
compared to the base case [268]. Another possibility is to use an on-site CCU technology that would avoid the need for $\mathrm{CO}_{2}$ transport and storage and their associated energy demand. One example is the utilization of carbon from post-combustion treatment in a Brazilian sugarcane factory [285]. Using co-electrolysis of $\mathrm{CO}_{2}$ and water, and methane synthesis, additional methane can be produced on-site. With this scheme, the Brazilian sugarcane factory managed to convert $54 \%$ of the total sugarcane carbon to useful end-use products, compared with the initial carbon efficiency of $17 \%$ [285].

Much work on the potential of CCS and CCU has been carried out, yet there is still a lack of holistic energy modelling papers that explicitly compared zero-carbon energy systems that included CCS with zero-carbon energy systems that do not include CCS. It is not clear whether the total energy system costs would be favourable in either of those two cases in the future energy systems. While life cycle analysis framework for CCS systems exists [286], it is still not available for CCU systems [287]. In their article [288], authors reviewed different LCA studies of CCS and CCU technologies, and investigated their environmental impacts, pointing that $\mathrm{CCU}$ is more profitable, but has a bigger environmental impact as the products produced can emit emissions.

One important advantage of CCU is that if appropriate electrolysis technology is used, the flexibility of the whole energy system can be increased. Hydrogen produced via electrolysis could be used directly in the future, or the syngas (a mixture of hydrogen, carbon monoxide and other gases) produced by combining carbon with electrolytic hydrogen could be transformed to different hydrocarbons using different syntheses processes [248]. The most beneficial electrolysis technology from the energy system point of view is solid-oxide electrolysis cell (SOEC), mainly due to its fast ramp-up and ramp-down possibilities. SOEC can be ramped-up from $0 \%$ to $100 \%$ capacity in a few seconds. However, during the cold start, ramping up the cell can take several hours [289]. Low-temperature proton exchange membrane electrolysis cell (LT PEM EC) has also a fast response within a part load range of 5-100\% [289]. It has also a relatively short cold start time of only 5 minutes. Schmidt et al. [290] report that the PEM electrolysis has a fastest cold start under 20 minutes, while SOEC and alkaline are under 60 min, while system response rates are in milliseconds for PEM and on the seconds level for SOEC and alkaline. Some manufacturers claimed that alkaline cells could be developed to include flexible running possibility, if the demand for that kind of cells would increase 289]. 


\section{Limitations, challenges and future research perspectives}

The great challenge of integrating carbon capture in the energy systems is the high and long-term investments and finding the most suitable end-utilisation of the collected carbon. Integrating different industrial actors to invest and to use CCU or CCS technologies is remaining challenging. The low carbon pricing and carbon policy is not supporting implementation of these technologies.

Carbon capture has also a technical challenge of collection and purification of $\mathrm{CO}_{2}$ from different sources and intermittent operation of the capture itself is not yet fully investigated nor demonstrated on the large scale. It is also possible that the capability to sequester carbon permanently may serve as an adverse incentive which further perpetuates the use of fossil energy, in contradiction of the ultimate purpose of the system. Or it can be seen as a supplement for renewable energy transition by using BECCS. Potentially unresolved issues such as storage safety and leakage of stored carbon are still debated, though according to [291] these issues can be avoided by careful selection of storage sites and $\mathrm{CO}_{2}$ monitoring. One of the critical obstacles for implementing CCU in the energy systems is a lack of clear system boundaries for the emission assessment and in some cases system analysis, coupled with lacking policy incentives. Another limitation is connected with the lack of established decision support schemes for planning CCUS infrastructure, as well as matching carbon sources and sinks [292]. It is yet unclear how should the decisions be made, e.g. whether the closest sink should be matched to the closest carbon sources or if priority should be given on some other method [292].

Literature also reveals that there is a lack of energy planning tools that would integrate CCUS planning, including matching of carbon sources and sinks, pipeline planning, as well as integrating CCUS to the energy system [293].

Integrated CCUS concept may have limitations and potential disadvantages. For example, tightly integrated systems that achieve high levels of efficiency and sustainability are vulnerable to cascading failures from internal (e.g., failure of equipment) or external disruptions (e.g., loss of supply of vital feedstocks) [294]. Integrated energy systems need to be built as resilient systems, however, the complexity of system operation of integrated system needs to be considered. Such systems must be planned with provisions for flexibility, redundancy or abnormal operating modes. In depth discussion of these issues is beyond the scope of this paper, but may be the topic of future research.

Finally, the literature reveals that CCUS is still relatively immature technology compared to the other existing low-carbon technologies, missing large demonstration sites in 
different environments [293]. There are also possible limitations that are yet unknown as they are many uncertainties in regard to this technology, such as lack of developed carbon markets, lack of long-term assessment of the CCUS operation, and data uncertainty [295].

As reported by Child et al. [296] flexible electricity generation, grid exchange and storage, both short and long term energy storages, support the energy transition. CCU products and related technologies as the final step of the energy transition, a fully 100\% RES energy system, still need to be studied in more detail. Nowadays, researchers are focused on issues of carbon capture, storage and utilization separately, while synergies and process integration are unexplored. Integration of CCUS technologies with existing systems, interaction with the energy production and $\mathrm{CO} 2$ utilization pathways is to be investigated. It should be noted that due to a number of different CCUS technologies and their different TRL level, it will be complicated to integrate them with the energy system. There have been number of laboratory studies on different CCUS technologies and their operating conditions. However, there is a lack of demo-scale and commercial CCUS technology applications in industrial environment. These are required to investigate technical problems of such technologies, their operating conditions and reliability, especially under flexible operating conditions. In the CCUS research area, due to the challenges named above, future research should be directed to these topics.

\section{Conclusions}

This review paper surveys and discusses the latest findings related to the integration of VRES based energy systems and CCU technologies. The importance of such integration and resulting synergistic effects are highlighted. It is stressed that flexible CCU technologies will be needed to meet future energy demands using 100\% RES energy system. These technologies can help stabilize volatile RES energy system by virtual storage of excess energy in a wide range of fuels and chemicals. The benefits from using the CCU technologies in this manner are the improvement of security of energy supply by reducing fossil fuel dependence, and the reduction of GHG emissions for mitigation of climate change.

Pre- and post-combustion CC technologies are especially promising for integration with energy systems. Their inherent flexibility can allow these two CC technologies to be used for balancing the electricity supply and demand in the power grid. In such systems, technoeconomic penalties relative to steady-state capture systems can be offset by variations in 
electricity price in a renewable-intensive power grid. This is significant since, in future energy systems, there will be a need for fast dynamic response technologies.

Lastly, the paper summarizes the options for utilization of captured $\mathrm{CO}_{2}$. The $\mathrm{CO}_{2}$ can either be used directly, or as raw material for manufacturing chemical products; a significant number of potential $\mathrm{CO}_{2}$ utilization pathways were surveyed and discussed. However, it needs to be emphasized that there is a large difference in scale (by orders of magnitude) between the potential market for $\mathrm{CO}_{2}$ as feedstock, and the amount that needs to be removed to be significant for climate stabilization purposes. For the latter issue, NETs like BECCS and DAC-CCS will be essential. However, further research in this area is needed to accelerate the development of technologies for climate stabilization.

\section{Acknowledgements}

The co-authors Mikulčić and Wang greatly acknowledge the Post-doctoral international exchange program by the China Postdoctoral Foundation, the National Key Research and Development Program of China (No. 2017YFB0603902), and the financial support of the National Natural Science Foundation of China (No. 51676157). The co-author Ridjan Skov greatly acknowledges the funding contribution from EP2Gas project EUDP no.64017-0011. The co-author Dominković was financed by the CITIES project nr. DSF1305-00027B funded by the Danish Innovationsfonden. Its contribution is greatly acknowledged. The authors would like to thank the financial support from Universiti Teknologi Malaysia Research University Fund under Vote Numbers Q.J130000.3509.05G96 and Q.J130000.21A2.04E44.

\section{References}

[1] IPCC, 2018: Summary for Policymakers. In: Global warming of $1.5^{\circ}$ C. An IPCC Special Report on the impacts of global warming of $1.5^{\circ} \mathrm{C}$ above pre-industrial levels and related global greenhouse gas emission pathways, in the context of strengthening the global response to the threat of climate change, sustainable development, and efforts to eradicate poverty (V. Masson-Delmotte, P. Zhai, H. O. Pörtner, D. Roberts, J. Skea, P. R. Shukla, A. Pirani, W. Moufouma-Okia, C. Péan, R. Pidcock, S. Connors, J. B. R. Matthews, Y. Chen, X. Zhou, M. I. Gomis, E. Lonnoy, T. Maycock, M. Tignor, T. Waterfield, eds.). World Meteorological Organization, Geneva, Switzerland.

[2] Mennicken L, Janz A, Roth S. 2016. The German R\&D Program for CO2 UtilizationInnovations for a Green Economy. Environmental Science and Pollution Research 23, 
11386-11392.

[3] Walmsley TG, Ong BHY, Klemeš JJ, Tan RR, Varbanov PS. 2019. Circular Integration of processes, industries, and economies. Renewable and Sustainable Energy Reviews 107, 507-515.

[4] Eveloy V, Gebreegziabher T. A review of projected power-to-gas deployment scenarios. Energies 2018; 11: Article 1824.

[5] Haszeldine RS, Flude S, Johnson G, Scott V. 2018 Negative emissions technologies and carbon capture and storage to achieve the Paris Agreement commitments. Phil. Trans. R. Soc. A 376: 20160447. doi.org/10.1098/rsta.2016.0447

[6] Merino-Garcia I, Alvarez-Guerra E, Albo J, Irabien A. Electrochemical membrane reactors for the utilisation of carbon dioxide. Chem Eng J 2016;305: 104-120. doi:10.1016/j.cej.2016.05.032

[7] Liu HJ, Were P, Li, Q, Gou, Y, Hou, Z. Worldwide Status of CCUS Technologies and Their Development and Challenges in China. Geofluids 2017; Article ID 6126505, https://doi.org/10.1155/2017/6126505.

[8] Koytsoumpa EI, Bergins C, Kakaras E. The $\mathrm{CO}_{2}$ economy: Review of $\mathrm{CO}_{2}$ capture and reuse technologies. J Supercrit Fuel 2018; 132: 3-16.

[9] Marocco Stuardi F, MacPherson F, Leclaire J. Integrated CO2 capture and utilization: A priority research direction. Current Opinion in Green and Sustainable Chemistry 2019; 16:71-76.

[10] Jarvis SM, Samsatli S. Technologies and infrastructures underpinning future CO2 value chains: A comprehensive review and comparative analysis. Renew Sustain Energy Rev 2018;85:46-68. doi:10.1016/J.RSER.2018.01.007.

[11] Al-Mamoori A, Krishnamurthy A, Rownaghi AA, Rezaei F. Carbon Capture and Utilization Update. Energy Technol 2017; 5: 834 - 849.

[12] Norhasyima RS, Mahlia TMI. Advances in $\mathrm{CO}_{2}$ utilization technology: A patent landscape review. $\mathrm{J} \mathrm{CO}_{2}$ Utilization 2018; 26: 323-335.

[13] Scopus, 2019. SCOPUS Database, Advanced Search https:// www.scopus.com/search/form.uri?display=basic\&clear=t\&origin=searchauthorlookup \&txGid=daa3cceb6bc106a96b49db8de4ea0ad0, (accessed July 28, 2019).

[14] International Energy Agency. Energy and Climate Change. 2015. Paris, France. 
doi:10.1038/479267b.

[15] World Health Organization. Air pollution levels rising in many of the world's poorest cities 2016. Geneva, Switzerland.

[16] Roser M. Our World in Data 2018. https://ourworldindata.org/ (accessed November 18, 2018).

[17] Ma XW, Ye Y, Shi XQ, Zou L Le. Decoupling economic growth from CO2emissions: A decomposition analysis of China's household energy consumption. Adv Clim Chang Res 2016;7:192-200. doi:10.1016/j.accre.2016.09.004.

[18] Enevoldsen MK, Ryelund A V., Andersen MS. Decoupling of industrial energy consumption and CO2-emissions in energy-intensive industries in Scandinavia. Energy Econ 2007;29:665-92. doi:10.1016/j.eneco.2007.01.016.

[19] Mikayilov JI, Hasanov FJ, Galeotti M. Decoupling of CO2 emissions and GDP: A timevarying cointegration approach. Ecol Indic 2018;95:615-28. doi:10.1016/j.ecolind.2018.07.051.

[20] Tapio P, Banister D, Luukkanen J, Vehmas J, Willamo R. Energy and transport in comparison: Immaterialisation, dematerialisation and decarbonisation in the EU15 between 1970 and 2000. Energy Policy 2007;35:433-51. doi:10.1016/J.ENPOL.2005.11.031.

[21] IRENA (2018), Renewable capacity statistics 2018, International Renewable Energy Agency (IRENA), Abu Dhabi, United Arab Emirates.

[22] International Energy Agency (IEA). World Energy Outlook 2018. 2018. Paris, France.

[23] Dominković DF. Modelling Energy Supply of Future Smart Cities. Technical University of Denmark, 2018. doi:https://doi.org/10.11581/dtu:00000038.

[24] International Renewable Energy Agency (IRENA). Renewable Power Generation Costs in 2017. Abu Dhabi, United Arab Emirates 2018.

[25] Dominković DF, Bačeković I, Ćosić B, Krajačić G, Pukšec T, Duić N, et al. Zero carbon energy system of South East Europe in 2050. Appl Energy 2016;184. doi:10.1016/j.apenergy.2016.03.046.

[26] Connolly D, Mathiesen BV, Ostergaard PA, Moller B, Nielsen S, Lund H, et al. Heat Roadmap Europe 2050. Second pre-study for the EU27. 2013. 
[27] Jacobson MZ, Delucchi MA, Bazouin G, Bauer ZAF, Heavey CC, Fisher E, et al. Environmental Science the 50 United States $†$. Energy Environ Sci 2015;8:2093-117. doi:10.1039/C5EE01283J.

[28] Clack CTM, Qvist SA, Apt J, Bazilian M, Brandt AR, Caldeira K, et al. Evaluation of a proposal for reliable low-cost grid power with $100 \%$ wind, water, and solar. PNAS 2017:3-8.

doi:10.1073/pnas.1610381114//DCSupplemental.www.pnas.org/cgi/doi/10.1073/pnas.1610381114.

[29] Jacobson BMZ. Questions and Answers Concerning the Lawsuit Around The Paper PNAS $114,6722-6727$ ( 2017 ) ( hereinafter C17 ) 2018;6727:6722-7. doi:10.1016/j.joule.2017.07.005.

[30] Hearda BP, Brookb BW, Wigleya TML, Bradshawd CJA. Burden of proof: A comprehensive review of the feasibility of $100 \%$ renewable-electricity systems. Renew Sustain Energy Rev 2018;76:1122-33. doi:10.1016/j.rser.2017.03.114.

[31] Brown TW, Bischof-Niemz T, Blok K, Breyer C, Lund H, Mathiesen B V. Response to 'Burden of proof: A comprehensive review of the feasibility of $100 \%$ renewableelectricity systems.' Renew Sustain Energy Rev 2018;92:834-47. doi:10.1016/j.rser.2018.04.113.

[32] Lund H, Werner S, Wiltshire R, Svendsen S, Thorsen JE, Hvelplund F, et al. 4th Generation District Heating (4GDH). Integrating smart thermal grids into future sustainable energy systems. Energy 2014;68:1-11. doi:10.1016/j.energy.2014.02.089.

[33] Nastasi B, Lo Basso G. Hydrogen to link heat and electricity in the transition towards future Smart Energy Systems. Energy 2016;110:5-22. doi:10.1016/j.energy.2016.03.097.

[34] Connolly D, Mathiesen B V., Ridjan I. A comparison between renewable transport fuels that can supplement or replace biofuels in a $100 \%$ renewable energy system. Energy 2014;73:110-25. doi:10.1016/j.energy.2014.05.104.

[35] Dominković DF, Bačeković I, Sveinbjörnsson D, Pedersen AS, Krajačić G. On the way towards smart energy supply in cities: The impact of interconnecting geographically distributed district heating grids on the energy system. Energy 2017:20. doi:10.1016/j.energy.2017.02.162.

[36] Mathiesen BV, Lund H, Connolly D, Wenzel H, Østergaard P a., Möller B, et al. Smart 
Energy Systems for coherent 100\% renewable energy and transport solutions. Appl Energy 2015;145:139-54. doi:10.1016/j.apenergy.2015.01.075.

[37] Ridjan I. Integrated electrofuels and renewable energy systems. Department of Development and Planning, 2015. Copenhagen, Denmark.

[38] Lund H, Mathiesen BV. Energy system analysis of 100\% renewable energy systemsThe case of Denmark in years 2030 and 2050. Energy 2009;34:524-31. doi:10.1016/j.energy.2008.04.003.

[39] Krajačić, G., Duić, N., Carvalho, M.G. 2011. How to achieve a 100\% RES electricity supply for Portugal? Applied Energy 88, 508-517.

[40] Connolly, D., Mathiesen, B. V. 2014. A technical and economic analysis of one potential pathway to a $100 \%$ renewable energy system. International Journal of Sustainable Energy Planning and Management, 1, 7-28.

[41] Krajačić, G., Duić, N., Zmijarević, Z., Mathiesen, B.V., Anić Vučinić, A., Carvalho, M.G. 2011a. Planning for a 100\% independent energy system based on smart energy storage for integration of renewables and $\mathrm{CO}_{2}$ emissions reduction. Applied Thermal Engineering 31, 2073-2083.

[42] Mathiesen BV, Lund H, Hansen K, Ridjan I, Djørup S, Nielsen S, et al. IDA's Energy Vision 2050. Copenhagen, Denmark: Aalborg University; 2015.

[43] Dominković DF, Dobravec V, Jiang Y, Nielsen PS, Krajačić G. Modelling smart energy systems in tropical regions. Energy 2018;155:592-609. doi:10.1016/j.energy.2018.05.007.

[44] Dominkovic DF, Stark G, Hodge BM, Pedersen AS. Integrated energy planning with a high share of variable renewable energy sources for a Caribbean Island. Energies 2018;11. doi:10.3390/en11092193.

[45] Duić, N. 2015. Is the success of clean energy guaranteed? Clean Technologies and Environtal Policy 17, 2093- 2100.

[46] Perković, L., Mikulčić, H., Pavlinek, L., Wang, X., Vujanović, M., Tan, H., Baleta, J., Duić, N., 2017. Coupling of cleaner production with a day-ahead electricity market: A hypothetical case study. J. Clean. Prod. 143, 1011-1020.

[47] Perković, L., Mikulčić, H., Duić, N., 2017. Multi-objective optimization of a simplified factory model acting as a prosumer on the electricity market. J. Clean. Prod. 167, 1438- 
1449.

[48] Connolly, D., Lund, H., Mathiesens, B.V. 2016. Smart Energy Europe: The technical and economic impact of one potential 100\% renewable energy scenario for the European Union. Renewable and Sustainable Energy Reviews 60, 1634-1653.

[49] Schlögl, R; Abanades, C; Aresta, M; Blekkan, EA; Cantat, T; Centi, G; Duic, N; El Khamlichi, A; Hutchings, G; Mazzotti, M; Mikulcic, H. Novel carbon capture and utilisation technologies. SAPEA, Science Advice for Policy by European Academies Report (2018) https://www.sapea.info/wp-content/uploads/CCU-report-proof3-for-23May.pdf

[50] EUROSTAT Statistics explained, Renewable energy statistics. 2017. http://ec.europa.eu/eurostat/statistics-explained/index.php/Renewable_energy_statistics

[51] Lund, H., Möller, B., Mathiesen, B.V., Dyrelund, A. 2010. The role of district heating in future renewable energy systems. Energy, 35, 1381-1390.

[52] BP Energy Economics. 2018 BP Energy Outlook 2018 BP Energy Outlook. 2018. doi:10.1088/1757-899X/342/1/012091.

[53] A Roadmap for Moving to a Competitive Low Carbon Economy in 2050, Communication from the Commission to the European Parliament, the Council, the European Economic and Social Committee and the Committee of the Regions 2011. Brussels, Belgium.

[54] García-Olivares A, Solé J, Osychenko O. Transportation in a 100\% renewable energy system. Energy Convers Manag 2018;158:266-85. doi:10.1016/J.ENCONMAN.2017.12.053.

[55] Anable J, Brand C, Tran M, Eyre N. Modelling transport energy demand: A sociotechnical approach. Energy Policy 2012;41:125-38. doi:10.1016/J.ENPOL.2010.08.020.

[56] Dominković DF, Bačeković I, Pedersen AS, Krajačić G. The future of transportation in sustainable energy systems: Opportunities and barriers in a clean energy transition. Renew Sustain Energy Rev 2018;82:1823-38. doi:10.1016/j.rser.2017.06.117.

[57] International Energy Agency (IEA). Global EV Outlook 2018 - Towards cross-modal electrification. 2018. Paris, France.

[58] Lund H, Kempton W. Integration of renewable energy into the transport and electricity 
sectors through V2G. Energy Policy 2008;36:3578-87. doi:10.12693/APhysPolA.118.825.

[59] Šare A, Krajačić G, Pukšec T, Duić N. The integration of renewable energy sources and electric vehicles into the power system of the Dubrovnik region. Energy Sustain Soc 2015;5. doi:10.1186/s13705-015-0055-7.

[60] Figenbaum E. Perspectives on Norway's supercharged electric vehicle policy. Environ Innov Soc Transitions 2017;25:14-34. doi:10.1016/J.EIST.2016.11.002.

[61] Gagatsi E, Estrup T, Halatsis A. Exploring the Potentials of Electrical Waterborne Transport in Europe: The E-ferry Concept. Transp Res Procedia 2016;14:1571-80. doi:10.1016/J.TRPRO.2016.05.122.

[62] Connolly D. Economic viability of electric roads compared to oil and batteries for all forms of road transport. Energy Strateg Rev 2017;18:235-49. doi:10.1016/J.ESR.2017.09.005.

[63] McDowall W. Are scenarios of hydrogen vehicle adoption optimistic? A comparison with historical analogies. Environ Innov Soc Transitions 2016;20:48-61. doi:10.1016/J.EIST.2015.10.004.

[64] Sgobbi A, Nijs W, De Miglio R, Chiodi A, Gargiulo M, Thiel C. How far away is hydrogen? Its role in the medium and long-term decarbonisation of the European energy system. Int J Hydrogen Energy 2016;41:19-35. doi:10.1016/J.IJHYDENE.2015.09.004.

[65] Jacobson MZ, Delucchi MA, Cameron MA, Mathiesen B V. Matching demand with supply at low cost in 139 countries among 20 world regions with $100 \%$ intermittent wind, water, and sunlight (WWS) for all purposes. Renew Energy 2018;123:236-48. doi:10.1016/J.RENENE.2018.02.009.

[66] Hakawati R, Smyth BM, McCullough G, De Rosa F, Rooney D. What is the most energy efficient route for biogas utilization: Heat, electricity or transport? Appl Energy 2017;206:1076-87. doi:10.1016/J.APENERGY.2017.08.068.

[67] Börjesson M, Ahlgren EO, Lundmark R, Athanassiadis D. Biofuel futures in road transport - A modeling analysis for Sweden. Transp Res Part D Transp Environ 2014;32:239-52. doi:10.1016/J.TRD.2014.08.002.

[68] Ridjan I, Mathiesen BV, Connolly D. Terminology used for renewable liquid and gaseous fuels based on the conversion of electricity: a review. J Clean Prod 2015. 
doi:10.1016/j.jclepro.2015.05.117.

[69] Yilmaz N, Atmanli A. Sustainable alternative fuels in aviation. Energy 2017;140:137886. doi:10.1016/J.ENERGY.2017.07.077.

[70] Staples MD, Malina R, Suresh P, Hileman JI, Barrett SRH. Aviation CO2 emissions reductions from the use of alternative jet fuels. Energy Policy 2018;114:342-54. doi:10.1016/J.ENPOL.2017.12.007.

[71] Schmidt P, Batteiger V, Roth A, Weindorf W, Raksha T. Power-to-Liquids as Renewable Fuel Option for Aviation: A Review. Chemie Ing Tech 2018;90:127-40. doi:10.1002/cite.201700129.

[72] Goldmann A, Sauter W, Oettinger M, Kluge T, Schröder U, Seume JR, et al. A Study on Electrofuels in Aviation. Energies 2018;11. doi:10.3390/en11020392.

[73] Edenhofer O, Pichs-Madruga R, Sokona Y, Farahani E, Kadner S, Seyboth K, et al. Climate Change 2014: Mitigation of Climate Change. Contribution of Working Group III to the Fifth Assessment Report of the Intergovernmental Panel on Climate Change. Cambridge, United Kingdom: 2014.

[74] Lechtenböhmer S, Nilsson LJ, Åhman M, Schneider C. Decarbonising the energy intensive basic materials industry through electrification - Implications for future EU electricity demand. Energy 2016;115:1623-31. doi:10.1016/J.ENERGY.2016.07.110.

[75] Luh S, Budinis S, Schmidt TJ, Hawkes A. Decarbonisation of the Industrial Sector by means of Fuel Switching, Electrification and CCS. Comput Aided Chem Eng 2018;43:1311-6. doi:10.1016/B978-0-444-64235-6.50230-8.

[76] Ye L, Nayak-Luke R, Bañares-Alcántara R, Tsang E. Reaction: "Green” Ammonia Production. Chem 2017;3:712-4. doi:10.1016/J.CHEMPR.2017.10.016.

[77] Karakaya E, Nuur C, Assbring L. Potential transitions in the iron and steel industry in Sweden: Towards a hydrogen-based future? J Clean Prod 2018;195:651-63. doi:10.1016/J.JCLEPRO.2018.05.142.

[78] Brown T, Gambhir A, Florin N, Fennell P. Reducing CO2 emissions from heavy industry: a review of technologies and considerations for policy makers. London, United Kingdom: 2012.

[79] Lieder M, Rashid A. Towards circular economy implementation: a comprehensive review in context of manufacturing industry. J Clean Prod 2016;115:36-51. 
doi:10.1016/J.JCLEPRO.2015.12.042.

[80] Domenech T, Bleischwitz R, Doranova A, Panayotopoulos D, Roman L. Mapping Industrial Symbiosis Development in Europe_typologies of networks, characteristics, performance and contribution to the Circular Economy. Resour Conserv Recycl 2019;141:76-98. doi:10.1016/J.RESCONREC.2018.09.016.

[81] Mikulčić, H., Klemeš, J.J., Vujanović, M., Urbaniec, K., Duić, N. 2016. Reducing greenhouse gasses emissions by fostering the deployment of alternative raw materials and energy sources in the cleaner cement manufacturing process. Journal of Cleaner Production 136, 119-132.

[82] Eurostat. Agri-environmental indicator - greenhouse gas emissions - Statistics Explained n.d. https://ec.europa.eu/eurostat/statistics-explained/index.php/Agrienvironmental_indicator_-_greenhouse_gas_emissions (accessed May 22, 2019).

[83] Tubiello FN, Salvatore M, Ferrara AF, Golec C, Jacobs H, Flammini A, et al. The Contribution of Agriculture , Forestry and other Land Use activities to Global Warming , 1990 - 2012 2015:2655-60. doi:10.1111/gcb.12865.

[84] Bryngelsson D, Wirsenius S, Hedenus F, Sonesson U. How can the EU climate targets be met? A combined analysis of technological and demand-side changes in food and agriculture. Food Policy 2016;59:152-64. doi:10.1016/j.foodpol.2015.12.012.

[85] Wollenberg E, Richards M, Smith P, Havlík P, Obersteiner M, Tubiello FN, Herold M, Gerber P, Carter S, Reisinger A, van Vuuren DP, Dickie A, Neufeldt H, Sander BO, Wassmann R, Sommer R, Amonette JE, Falcucci A, Herrero M, Opio C, Roman-Cuesta RM, Stehfest E, Westhoek H, Ortiz-Monasterio I, Sapkota T, Rufino MC, Thornton PK, Verchot L, West PC, Soussana JF, Baedeker T, Sadler M, Vermeulen S, Campbell BM. Reducing emissions from agriculture to meet the $2^{\circ} \mathrm{C}$ target, Glob Chang Biol. 2016:3859-64. doi:10.1111/gcb.13340.

[86] Shcherbak I, Millar N, Robertson GP. Global metaanalysis of the nonlinear response of soil nitrous oxide (N2O) emissions to fertilizer nitrogen 2014;111:9199-204. doi:10.1073/pnas.1322434111.

[87] Franks JR, Hadingham B. Reducing greenhouse gas emissions from agriculture: Avoiding trivial solutions to a global problem. Land Use Policy 2012;29:727-36. doi:10.1016/J.LANDUSEPOL.2011.11.009. 
[88] Zhang L, Pang J, Chen X, Lu Z. Carbon emissions, energy consumption and economic growth: Evidence from the agricultural sector of China's main grain-producing areas. Sci Total Environ 2019;665:1017-25. doi:10.1016/J.SCITOTENV.2019.02.162.

[89] Liu X, Zhang S, Bae J. The impact of renewable energy and agriculture on carbon dioxide emissions: Investigating the environmental Kuznets curve in four selected ASEAN countries. J Clean Prod 2017;164:1239-47. doi:10.1016/j.jclepro.2017.07.086.

[90] Clark M, Tilman, D. Comparative analysis of environmental impacts of agricultural production systems, agricultural input efficiency, and food choice. Environmental Research Letters 12 111002, 2017.

[91] Qiao H, Zheng F, Jiang H, Dong K. The greenhouse effect of the agriculture-economic growth-renewable energy nexus: Evidence from G20 countries. Sci Total Environ 2019;671:722-31. doi:10.1016/J.SCITOTENV.2019.03.336.

[92] Zhang L, Pang J, Chen X, Lu Z. Carbon emissions, energy consumption and economic growth: Evidence from the agricultural sector of China's main grain-producing areas. Sci Total Environ 2019;665:1017-25. doi:10.1016/J.SCITOTENV.2019.02.162.

[93] Fertilizers Europe. Feeding Life 2030. Brussels, Belgium: 2018.

[94] Blandford D, Gaasland I, Vårdal E. The trade-off between food production and greenhouse gas mitigation in Norwegian agriculture. Agric Ecosyst Environ2014;184:59-66. doi:10.1016/J.AGEE.2013.11.025.

[95] Li B, Duan Y, Luebke D, Morreale B. Advances in $\mathrm{CO}_{2}$ capture technology: A patent review. Applied Energy 2013; 102: 1439-1447.

[96] Figueroa JD, Fout T, Plasynski S, Mcllvried H, Srivastava RD. Advances in $\mathrm{CO}_{2}$ capture technology - The US Department of Energy's Carbon Sequestration Program. International Journal of Greenhouse Gas Control 2008; 2: 9-20.

[97] Hetland J, Yowargana P, Leduc S, Kraxner F. Carbon-negative emissions: Systemic impacts of biomass conversion. A case study on $\mathrm{CO}_{2}$ capture and storage options. International Journal of Greenhouse Gas Control 2016; 49: 330-342.

[98] Bhave A, Taylor RHS, Fennell P, Livingston WR, Shah N, MacDowell N, Dennis J, Kraft M, Pourkashanian M, Insa M, Jones J, Burdett N, Bauen A, Beal C, Smallbone A, Akroyd J. Screening and techno-economic assessment of biomass-based power 
generation with CCS technologies to meet $2050 \mathrm{CO}_{2}$ targets. Applied Energy 2017; 190: 481-489.

[99] Bui M, Adjiman CS, Bardow A, Anthony EJ, Boston A, Brown S, et al., Carbon capture and storage (CCS): the way forward. Energy \& Environmental Science way 2018; 5: 1062-1176.

[100] Wall TF. Combustion processes for carbon capture. Proceedings of the Combustion Institute 2007; 31: 31-47.

[101] Cormos C-C. Integrated assessment of IGCC power generation technology with carbon capture and storage (CCS). Energy 2012; 42: 434-445.

[102] Cormos A-M, Dinca, Cormos C-C. Multi-fuel multi-product operation of IGCC power plants with carbon capture and storage (CCS). Applied Thermal Engineering 2015; 74: $20-27$.

[103] Dinca C, Slavu N, Cormos C-C, Badea A. $\mathrm{CO}_{2}$ capture from syngas generated by a biomass gasification power plant with chemical absorption process. Energy 2018; 149: 925-936.

[104] Ortiz C., Valverde J.M., Chacartegui R., Romeo L.M., Perez-Maqueda L.A., 2018, The moxy-cal process: integration of membrane separation, partial oxy-combustion and calcium looping for co2 capture, Chemical Engineering Transactions, 70, 643-648 DOI:10.3303/CET1870108

[105] Luo J., Li W., Tian L., Liu L., 2017, Experimental and numerical study of oxygen diluted partially premixed dimethyl ether/ methane counter flow flame, Chemical Engineering Transactions, 61, 415-420 DOI:10.3303/CET1761067

[106] Toftegaard MB, Brix J, Jensen PA, Glarborg P, Jensen AD. Oxy-fuel combustion of solid fuels. Progress in Energy and Combustion Science 2010; 36: 581-625.

[107] Fryda L, Sobrino C, Cieplik M, Van De Kamp WL. Study of ash deposition under oxyfuel combustion of coal/biomass blends. Fuel 2010; 89; 1889-1902.

[108] Höltl W, Pröll T, Kronberger B, Rohovec J, Hofbauer H. Oxyfuel combustion for lowcalorific fuels. Proceedings of the 2008 Global Symposium on Recycling, Waste Treatment and Clean Technology, REWAS 2008, Cancun, Mexico, October 12-15, 2008, p.151-157. 
[109] Haykiri-Acma H, Turan AZ, Yaman S, Kucukbayrak S. Controlling the excess heat from oxy-combustion of coal by blending with biomass. Fuel Processing Technology 2010; 91: 1569-1575.

[110] Ishida M, Zheng D, Akehata T. Evaluation of a chemical-looping-combustion powergeneration system by graphic exergy analysis. Energy 1987; 12: 147-154.

[111] Mohd Rudin S.N.F., Muis Z.A., Hashim H., Ho W.S., 2017, Overview of carbon reduction, capture, utilization and storage: development of new framework, Chemical Engineering Transactions, 56, 649-654 DOI:10.3303/CET1756109

[112] Moldenhauer P, Sundqvist S, Mattisson T, Linderholm C. Chemical-looping combustion of synthetic biomass-volatiles with manganese-ore oxygen carriers. International Journal of Greenhouse Gas Control 2018; 71: 239-252.

[113] Schmitz M, Linderholm C. Chemical looping combustion of biomass in 10- and 100$\mathrm{kW}$ pilots - Analysis of conversion and lifetime using a sintered manganese ore. Fuel 2018; 231: 73-84.

[114] Song T, Shen L. Review of reactor for chemical looping combustion of solid fuels. International Journal of Greenhouse Gas Control 2018; 76: 92-110.

[115] Cormos C-C. Biomass direct chemical looping for hydrogen and power co-production: Process configuration, simulation, thermal integration and techno-economic assessment. Fuel Processing Technology 2015; 137: 16-23.

[116] Sanchez DL, Johnson N, McCoy ST, Turner PA, Mach KJ. Near-term deployment of carbon capture and sequestration from biorefineries in the United States. Proceedings of the National Academy of the United States of America 2018; 115: 4875-4880.

[117] Laude A, Ricci O, Bureau G, Royer-Adnot J, Fabbri A. $\mathrm{CO}_{2}$ capture and storage from a bioethanol plant: Carbon and energy footprint and economic assessment. International Journal of Greenhouse Gas Control 2011; 5: 1220-1231.

[118] Wang T, Hovland J, Jens KJ. Amine reclaiming technologies in post-combustion carbon dioxide capture. Journal of Environmental Science 2015; 27: 276-289.

[119] Abdeen F. R. H., Mel M., Jami M. S., Ihsan I., Ismail A. F. A review of chemical absorption of carbon dioxide for biogas upgrading. Chinese Journal of Chemical Engineering 2016; 24: 693-702.

[120] Fazlollahi F, Saeidi S, Safdari MS, Sarkari M, Klemeš JJ, Baxter LL. Effect of Operating 
Conditions on Cryogenic Carbon Dioxide Removal. Energy Technology 2017; 5, 15881598.

[121] Araújo OQF, de Medeiros JL. Carbon capture and storage technologies: present scenario and drivers of innovation. Current Opinion in Chemical Engineering 2017; 17: 22-34.

[122] Aaron D, Tsouris C. Separation of $\mathrm{CO}_{2}$ from flue gas: A review. Separation Science and Technology 2005; 40: 321-348.

[123] Ahmad M.Z., Hashim H., Yunus N.A., Lim J.S., Ho W.S., Ho C.S., 2017, A physical absorption assessment of a new alternative solvenet for carbon capture, Chemical Engineering Transactions, 56, 625-630 DOI:10.3303/CET1756105

[124] Le Moullec Y, Kanniche M. Screening of flowsheet modifcations for an efficient monoethanolamine (MEA) based post-combustion $\mathrm{CO}_{2}$ capture. International Journal of Greenhouse Gas Control 2011; 5: 727-740.

[125] Gouedard C, Picq D, Launay F, Carrette P-L. Amine degradation in $\mathrm{CO}_{2}$ capture. I. A review. International Journal of Greenhouse Gas Control 2012; 10: 244-270.

[126] Puxty G, Rowland R, Allport A, Yang Q, Bown M, Burns R, Maeder M, Attalla M. Carbon dioxide postcombustion capture: A novel screening study of the carbon dioxide absorption performance of 76 amines. Environmental Science and Technology 2009; 43: 6427-6433.

[127] MacDowell NM, Fajardy M. On the potential for BECCS efficiency improvement through heat recovery from both post-combustion and oxy-combustion facilities. Faraday Discussions 2016; 192: 241-250.

[128] Zhao B, Su Y, Tao W, Li L, Peng Y. Post-combustion $\mathrm{CO}_{2}$ capture by aqueous ammonia: A state-of-the-art review. International Journal of Greenhouse Gas Control 2012; 9: $355-371$.

[129] Brennecke JF, Gurkan BE. Ionic liquids for $\mathrm{CO}_{2}$ capture and emission reduction. Journal of Physical Chemistry Letters 2010; 1: 3459-3464.

[130] Janakiram S, Ahmadi M, Dai Z, Ansaloni L, Deng L. Performance of Nanocomposite Membranes Containing OD to 2D Nanofillers for $\mathrm{CO}_{2}$ Separation : A Review. Membranes 2018, 8(2), 24

[131] Asif M, Suleman M, Haq I, Jamal SA. Post-combustion $\mathrm{CO}_{2}$ capture with chemical absorption and hybrid system: current status and challenges. Greenhouse Gases: Science 
and Technology 2018; 8: 998-1031.

[132] Saqib S, Rafiq S, Chawla M, Saeed M, Muhammad N, Khurram S, et al. Facile $\mathrm{CO}_{2}$ Separation in Composite Membranes. Chemical Engineering \& Technology 2019; 42: $32-40$

[133] Norahim N, Yaisanga P, Faungnawakij K, Charinpanitkul T, Klaysom C. Recent Membrane Developments for CO2 Separation and Capture. Chemical Engineering \& Technology 2018; 41: 211-223.

[134] Sreedhar I, Vaidhiswaran R, Kamani BM, Venugopal A. Process and engineering trends in membrane based carbon capture. Renewable and Sustainable Energy Reviews 2017; 68: 659-684.

[135] Song C, Liu Q, Deng S, Li, H, Kitamura Y, Cryogenic-based $\mathrm{CO}_{2}$ capture technologies: State-of-the-art developments and current challenges. Renewable and Sustainable Energy Reviews 2019; 101: 265-278.

[136] Lively RP, Koros WJ, Johnson JR. Enhanced cryogenic $\mathrm{CO}_{2}$ capture using dynamically operated low-cost fiber beds. Chemical Engineering Science 2012; 71: 97-103.

[137] Song C, Kitamura Y, Li S. Energy analysis of the cryogenic $\mathrm{CO}_{2}$ capture process based on Stirling coolers. Energy 2014; 65: 580-589.

[138] Song C, Liu Q, Ji N, Deng S, Zhao J, Li Y, Kitamura Y. Reducing the energy consumption of membrane-cryogenic hybrid $\mathrm{CO}_{2}$ capture by process optimization. Energy 2017; 124: 29-39.

[139] Song C, Kitamura Y, Li SH. Evaluation of Stirling cooler system for cryogenic $\mathrm{CO}_{2}$ capture. Applied Energy 2012; 98: 491-501.

[140] Dean CC, Blamey J, Florin NH, Al-Jeboori MJ, Fennell PS. The calcium looping cycle for $\mathrm{CO}_{2}$ capture from power generation, cement manufacture and hydrogen production. Chemical Engineering Research and Design 2011; 89: 836-855.

[141] Sanz-Perez ES, Murdock CR, Didas SA, Jones CW. Direct capture of $\mathrm{CO}_{2}$ from ambient air. Chemical Reviews 2016; 116: 11840-11876.

[142] Pritchard C, Yang H, Holmes P, Wilkinson M. Thermodynamics, economics and systemsthinking: What role for air capture of $\mathrm{CO}_{2}$ ? Process Safety and Environmental Protection 2015; 94: 188-195. 
[143] Chen C, Tavoni M. Direct air capture of $\mathrm{CO}_{2}$ and climate stabilization: A model based assessment. Climate Change 2013; 118: 59-72.

[144] Lackner KS, Ziock H, Grimes P. Carbon dioxide extraction from air: Is it an option? Proceedings of the $24^{\text {th }}$ Annual Technical Conference on Coal Utilization and Fuel Systems, Clearwater, Florida, USA, 1999; p. 885-896.

[145] McLaren D. A comparative global assessment of potential negative emissions technologies. Process Safety and Environmental Protection 2012; 90: 489-500.

[146] House KZ, Baclig AC, Ranjan M, Van Nierop EA, Wilcox J, Herzog HJ. Economic and energetic analysis of capturing $\mathrm{CO}_{2}$ from ambient air. Proceedings of the National Academy of Sciences of the United States of America 2011; 108: 20428-20433.

[147] Nikulshina V, Galvez ME, Steinfeld A. Kinetic analysis of the carbonation reactions for the capture of $\mathrm{CO}_{2}$ from air via the $\mathrm{Ca}(\mathrm{OH})_{2}-\mathrm{CaCO}_{3}-\mathrm{CaO}$ solar thermochemical cycle. Chemical Engineering Journal 2007; 129: 75-83.

[148] Nikulshina V, Ayesa N, Galvez ME, Steinfeld A. Feasibility of Na-based thermochemical cycles for the capture of $\mathrm{CO} 2$ from air - thermodynamic and thermogravimetric analyses. Chemical Engineering Journal 2008; 140: 62-70.

[149] Wang C, Liu H, Li X, Zheng L. Importance of ambient $\mathrm{O}_{2}$ for electrochemical enrichment of atmospheric $\mathrm{CO}_{2}$. Industrial and Engineering Chemistry Research 2013; 52: $2470-2476$.

[150] Abdilahi AM, Mustafa MW, Abujarad SY, Mustapha M. Harnessing flexibility potential of flexible carbon capture power plants for future low carbon power systems: Review. Renewable and Sustainable Energy Reviews 2018; 81: 3101-3110.

[151] Chalmers H, Leach M, Lucquiaud M, Gibbins J. Valuing flexible operation of power plants with $\mathrm{CO}_{2}$ capture. Energy Procedia 2009; 1: 4289-4296.

[152] Cohen SM, Rochelle GT, Webber ME. Optimal operation of flexible post-combustion $\mathrm{CO}_{2}$ capture in response to volatile electricity prices. Energy Procedia 2011; 4: 2604 2611 .

[153] Tait P, Buschle B, Ausner I, Valluri P, Wehrli M, Lucquiaud M. A pilot-scale study of dynamic response scenarios for the flexible operation of post-combustion $\mathrm{CO}_{2}$ capture. International Journal of Greenhouse Gas Control 2016; 48: 216-233. 
[154] Haszeldine R. S. Carbon capture and storage: How green can black be? Science 2009; 325: 1647-1652.

[155] Domenichini R, Mancuso L, Ferrari N, Davison J. Operating Flexibility of Power Plants with Carbon Capture and Storage (CCS). Energy Procedia 2013; 37: 2727-2737.

[156] Ajiwobowo MW, Darmawan A, Aziz M. 2018. A conceptual chemical looping combustion power system design in a power-to-gas energy storage scenario. International Journal of Hydrogen Energy (in press, DOI:10.1016/j.ijhydene.2018.11.177).

[157] Aghajani H, Race JM, Wetenhall B, Sanchez-Fernandez E, Lucquiaud M, Chalmers H. On the potential for interim storage in dense phase $\mathrm{CO}_{2}$ pipelines. International Journal of Greenhouse Gas Control 2017; 66: 276-287.

[158] Wohland J, Witthaut D, Schleussner C-F. Negative emission potential of direct air capture powered by renewable excess electricity in Europe. Earth's Future 2018; 6: $1380-1384$.

[159] Nurariffudin M., Hashim H., Lim J.S., Ho C.S., 2017, Economic assessment of microalgae-based $\mathrm{CO}_{2}$ utilization in power plant sector in Malaysia, Chemical Engineering Transactions, 56, 643-648 DOI:10.3303/CET1756108

[160] Chen J, Wang Y, Benemann JR, Zhang X, Hu H, Qin S. Microalgal industry in China: challenges and prospects. Journal of Applied Phycology 2016; 28: 715-725.

[161] Zhang Q, Nurhayati, Cheng, CL, Nagarajan, D, Chang, JS, Hu, J, Lee, DJ. Carbon capture and utilization of fermentation $\mathrm{CO}_{2}$ : Integrated ethanol fermentation and succinic acid production as an efficient platform. Applied Energy 2017; 206: 364-371.

[162] Zeikus JG, Jain MK, Elankovan P. Biotechnology of succinic acid production and markets for derived industrial products. Applied Microbiology and Biotechnology 1999; 51: $545-552$.

[163] Aresta M, Dibenedetto A, Angelini A. The changing paradigm in $\mathrm{CO}_{2}$ utilization. Journal of $\mathrm{CO}_{2}$ utilization $2013 ; 3: 65-73$.

[164] Global CCS Institute (2014) Status of CCS project database. http://www.globalccsinstitute.com/projects/status-ccs-project-database. Accessed 22 November 2018

[165] Peters M, Kohler B, Kuckshinrichs W, Leitner W, Markewitz P, Muller TE, Chemical 
Technologies for exploiting and recycling carbon dioxide into the value chain. ChemSusChem, Special issue: carbon dioxide recycling 4:9. 2011;4:1216-1240.

[166] Aresta M, Dibenedetto A, in Greenhouse Gas Sinks, ed. D. Reay, C. Hewitt, K. Smith and J. Grace, CABI Publishing, Wallingford UK, 2007, ch. 7, pp. 98-114.

[167] Zanchi V, Boban L, Soldo V. Refrigerant Options in the Near Future, J. sustain. dev. energy water environ.syst., 2019 DOI: https://doi.org/10.13044/j.sdewes.d6.0250

[168] Emani MS, Mandal BK. The Use of Natural Refrigerants in Refrigeration and Air Conditioning Systems: A Review. IOP Conference Series: Materials Science and Engineering, Volume 377, no. 1, 2018.

[169] Abas N, Kalair AR, Khan N, Haider A, Saleem Z, Saleem MS. Natural and synthetic refrigerants, global warming: A review. Renewable and Sustainable Energy Reviews 2018; 90: 557-569.

[170] Sharma V, Fricke B, Bansal P. Comparative analysis of various $\mathrm{CO}_{2}$ configurations in supermarket refrigeration systems. International Journal of Refrigeration 2014; 46: 8699.

[171] Wu W, Skye HM. Progress in ground-source heat pumps using natural refrigerants. International Journal of Refrigeration 2018; 92: 70-85.

[172] Badache M, Ouzzane M, Eslami-Nejad P, Aidoun Z. Experimental study of a carbon dioxide direct-expansion ground source heat pump ( $\mathrm{CO}_{2}$-DX-GSHP). Applied Thermal Engineering 2018; 130: 1480-1488.

[173] Ghazizade-Ahsaee H, Ameri M. Effects of using Expander and Internal Heat Exchanger on Carbon Dioxide Direct-Expansion Geothermal Heat Pump. Applied Thermal Engineering 2018; 136: 389-407.

[174] Wang, Z, Wang F, Ma Z, Lin W, Ren H. Investigation on the feasibility and performance of transcritical $\mathrm{CO}_{2}$ heat pump integrated with thermal energy storage for space heating. Renewable Energy 2019; 134: 496-508.

[175] Bedoić, R., Filipan, V., Heating Performance Analysis of a Geothermal Heat Pump Working with Different Zeotropic and Azeotropic Mixtures, J. sustain. dev. energy water environ. syst., 6(2), pp 240-253, 2018, DOI: https://doi.org/10.13044/j.sdewes.d5.0189

[176] Wang D, Yu B, Li W, Shi J, Chen J. Heating performance evaluation of a $\mathrm{CO}_{2}$ heat pump system for an electrical vehicle at cold ambient temperatures. Applied Thermal 
Engineering 2018; 142: 656-664.

[177] Alper E, Orhan OY. $\mathrm{CO}_{2}$ utilization: Developments in conversion processes. Petroleum 2017; 3:109-126

[178] von der Assen N, Jung J, Bardow A. Life-cycle assessment of carbon dioxide capture and utilization: avoiding the pitfalls. Energy Environ Sci 2013;6: 2721-2734.

[179] Quadrelli EA, Centi G, Duplan J-L, Perathoner S. Carbon Dioxide Recycling: Emerging Large-Scale Technologies with Industrial Potential. ChemSusChem 2011;4:1194 1215.

[180] Sakakura T, Choi J-C, Yasuda H. Transformation of Carbon Dioxide. Chem Rev 2007; 107:2365-2387.

[181] Romero M, Steinfeld A. Concentrating solar thermal power and thermochemical fuels. Energy Environ Sci 2012;5:9234-9245.

[182] Kim J, Henao CA, Johnson TA, Dedrick DE, Miller JE, Stechel EB, Maravelias CT. Methanol production from $\mathrm{CO}_{2}$ using solar-thermal energy: process development and techno-economic analysis. Energy Environ Sci 2011;4:3122-3132.

[183] Havran V, Dudukovi'c MP, Lo CS. Conversion of Methane and Carbon Dioxide to Higher Value Products. Ind. Eng. Chem. Res 2011; 50: 7089-7100.

[184] Behr A, Oberreuther T, Wolff C, Generation of synthesis gas by dry plasma reforming. Chem Eng Technol 2004; 76: 951 - 955.

[185] Sridhar KR, Vaniman BT. Oxygen production on Mars using solid oxide electrolysis. Solid State Ionics 1997; 93: 321-328.

[186] Sridhar S, Stancovski V, Pal UB. Effect of oxygen-containing species on the impedance of the Pt/ Y SZ interface. Solid State Ionics 1997; 100: 17-22.

[187] Tao G, Sridhar KR, Chan CL. Study of carbon dioxide electrolysis at electrode/electrolyte interface: Part I. Pt/YSZ interface. Solid State Ionics 2004a; 175:615-619.

[188] Tao G, Sridhar KR, Chan CL. Study of carbon dioxide electrolysis at electrode/electrolyte interface: Part II. Pt-YSZ cermet/YSZ interface. Solid State Ionics 2004b; 175:621-624.

[189] Zhan Z, Zhao L. Electrochemical reduction of $\mathrm{CO}_{2}$ in solid oxide electrolysis cells. Journal of Power Sources 2010;195:7250-7254.

[190] Furukawa S, Okada M, Suzuki Y, Isolation of Oxygen Formed during Catalytic 
Reduction of Carbon Dioxide Using a Solid Electrolyte Membrane. Energy and Fuels 1999; 13:1074-1081.

[191] Kim T, Moon S, Hong S-I. Internal carbon dioxide reforming by methane over Ni-YSZ$\mathrm{CeO} 2$ catalyst electrode in electrochemical cell. Applied Catalysis A: General 2002; 224:111-120.

[192] Moon DJ, Park JM, Kang JS, Yoo KS, Hong SI. Cogeneration of a synthesis gas and electricity through internal reforming of methane by carbon dioxide in a solid oxide fuel cell system. J Ind Eng Chem 2006;12:149-155.

[193] Bidrawn F, Kim G, Corre G, Irvine JTS, Vohs JM, Gorte RJ. Efficient Reduction of $\mathrm{CO}_{2}$ in a Solid Oxide Electrolyzer. Electrochem Solid State Lett 2008;11:B167-B170.

[194] Huang T-J, Chou C-L. Electrochemical $\mathrm{CO}_{2}$ reduction with power generation in SOFCs with Cu-added LSCF-GDC cathode. Electrochem Commun 2009;11:1464-1467.

[195] Hori Y, Kikuchi K, Suzuki S. Production of $\mathrm{CO}$ and $\mathrm{CH}_{4}$ in electrochemical reduction of $\mathrm{CO}_{2}$ at metal electrodes in aqueous hydrogencarbonate solution. Chem Lett 1985;14:1695-1698.

[196] Hori Y, Kikuchi K, Murata A, Suzuki S. Production of methane and ethylene in electrochemical reduction of carbon dioxide at copper electrode in aqueous hydrogencarbonate solution. Chemistry Letters 1986; 15:897-898.

[197] Sobkowski J, Czerwinski A, Voltammetric study of carbon monoxide and carbon dioxide adsorption on smooth and platinized platinum electrodes. Journal of Physical Chemistry 1985;89:365-369.

[198] Ohkawa K, Hashimoto K, Fujishima A, Noguchi Y, Nakayama S. Electrochemical reduction of carbon dioxide on hydrogen storing materials. Journal of Electroanalytical Chemistry 1993a;345: 445-456.

[199] Ohkawa K, Noguchi Y, Nakayama S, Hashimoto K, Fujishima A. Electrochemical reduction of carbon dioxide on hydrogen storing materials. Part 1: The effect of hydrogen absorption on the electrochemical behavior on palladium electrodes. Journal of Electroanalytical Chemistry 1993b; 348: 459-464.

[200] Ohkawa K, Noguchi Y, Nakayama S, Hashimoto K, Fujishima A. Electrochemical reduction of carbon dioxide on hydrogenstoring materials. Part II:Copper-modified palladium electrode. Journal of Electroanalytical Chemistry 1994a; 367:165-173. 
[201] Ohkawa K, Noguchi Y, Nakayama S, Hashimoto K, Fujishima A, Electrochemical reduction of carbon dioxide on hydrogen-storing materials. Part 3. The effect of the absorption of hydrogen on the palladium electrodes modified with copper. Journal of Electroanalytical Chemistry 1994b; 369: 247-250.

[202] Chen Y, Li CW, Kanan MW. Aqueous $\mathrm{CO}_{2}$ Reduction at Very Low Overpotential on Oxide-Derived Au Nanoparticles. Journal of the American Chemical Society 2012;134: 19969-19972.

[203] Köleli F, Balun D. Aqueous $\mathrm{CO}_{2}$ Reduction at Very Low Overpotential on Oxide-Derived Au Nanoparticles. Applied Catalysis A: General 2004;274:237-242.

[204] Machunda RL, Ju H, Lee J. Reduction of $\mathrm{CO}_{2}$ under high pressure and high temperature on $\mathrm{Pb}$-granule electrodes in a fixed-bed reactor in aqueous medium. Current Applied Physics 2011;11: 986-988.

[205] Summers DP, Leach S, Frese Jr KW. Electrocatalytic reduction of $\mathrm{CO}_{2}$ gas at $\mathrm{Sn}$ based gas diffusion electrode. The electrochemical reduction of aqueous carbon dioxide to methanol at molybdenum electrodes with low overpotentials. Journal of Electroanalytical Chemistry and Interfacial Electrochemistry 1986;205:219-232.

[206] Tripkovic V, Vanin M, Karamad M, Björketun ME, Jacobsen KW, Thygesen KS, Rossmeisl J. Electrochemical $\mathrm{CO}_{2}$ and $\mathrm{CO}$ reduction on metal-functionalized porphyrinlike graphene. The Journal of Physical Chemistry C 2013;117:9187-9195.

[207] Verdejo B, Blasco S, González J, García-Espana E, Gavina P, Tatay S, Doménech A, Doménech-Carbó MT, Jiménez HR, Soriano C. $\mathrm{CO}_{2}$ Fixation and Activation by CuII Complexes of 5,5-TerpyridinophaneMacrocycles. European Journal of Inorganic Chemistry 2008 2008;84-97.

[208] Angamuthu R, Byers P, Lutz M, Spek AL, Bouwman E. Electrocatalytic $\mathrm{CO}_{2}$ Conversion to Oxalate by a Copper Complex. Science 2010; 327:313-315.

[209] García-Espana E, Gavina P, Latorre J, Soriano C, Verdejo B, $\mathrm{CO}_{2}$ Fixation by Copper(II) Complexes of a Terpyridinophane Aza Receptor. Journal of the American Chemical Society 2004;126: 5082-5083.

[210] Hossain AGMM, Nagaoka T, Ogura K. Electrocatalytic reduction of carbon dioxide by substituted pyridine and pyrazole complexes of palladium. Electrochimica Acta 1996; 41:2773-2780. 
[211] Hossain AGMM, Nagaoka T, Ogura K. Palladium and cobalt complexes of substituted quinoline, bipyridine and phenanthroline as catalysts for electrochemical reduction of carbon dioxide. Electrochimica Acta 1997; 42: 2577-2585.

[212] Steffey BD, Curtis CJ, DuBois DL. Electrochemical reduction of $\mathrm{CO}_{2}$ catalyzed by a dinuclear palladium complex containing a bridging hexaphosphine ligand: Evidence for cooperativity organometallics 1995;14: 4937-4943.

[213] Rakowski Dubois M, Dubois DL, Electrochemical Reduction of $\mathrm{CO}_{2}$ to $\mathrm{CO}$ Catalyzed by a Bimetallic Palladium Complex. Accounts of Chemical Research 2009; 42:19741982.

[214] Beley M, Collin JP, Ruppert R, Sauvage JP. Development of Molecular Electrocatalysts for $\mathrm{CO}_{2}$ Reduction and $\mathrm{H}_{2}$ Production/Oxidation Journal of the American Chemical Society 1986;108: 7461-7467.

[215] Collin JP, Jouaiti A, Sauvage JP. Electrocatalytic reduction of carbon dioxide by nickel cyclam2+ in water: study of the factors affecting the efficiency and the selectivity of the process Inorganic Chemistry 1988;27:1986-1990

[216] Fujihira M, Hirata Y, Suga K. Electrocatalytic properties of (tetraazacyclotetradecane)nickel(2+) and $\mathrm{Ni2}$ (biscyclam)4+ with respect to carbon dioxide and water reduction. Journal of Electroanalytical Chemistry and Interfacial Electrochemistry 1990; 292: 199-215.

[217] Balazs GB, Anson FC. The adsorption of Ni(cyclam)+ at mercury electrodes and its relation to the electrocatalytic reduction of CO. Journal of Electroanalytical Chemistry $1992 ; 322: 325-345$.

[218] Balazs GB, Anson FC. Effects of CO on the electrocatalytic activity of Ni (cyclam) 2+ toward the reduction of CO. Journal of Electroanalytical Chemistry 1993;361:149-157.

[219] de Alwis C, Crayston JA, Cromie T, Eisenblätter T, Hay RW, Lampeka YD, Tsymbal LV. Cyclic voltammetry study of the electrocatalysis of carbon dioxide reduction by bis(polyazamacrocyclic) nickel complexes. Electrochimica Acta 2000;45:2061-2074.

[220] Simón-Manso E, Kubiak CP. Dinuclear nickel complexes as catalysts for electrochemical reduction of carbon dioxide. Organometallics 2004;24:96-102.

[221] Thoi VS, Chang CJ. Nickel N-heterocyclic carbene-pyridine complexes that exhibit selectivity for electrocatalytic reduction of carbon dioxide over water. Chemical 
Communications 2011; 47: 6578-6580.

[222] Shibata M, Furuya N, Simultaneous reduction of carbon dioxide and nitrate ions at gasdiffusion electrodes with various metallophthalocyanine catalysts. Electrochimica Acta 2003; 48:3953-3958

[223] Arana C, Yan S, Keshavarz-K M, Potts KT, Abruna HD, Electrocatalytic reduction of carbon dioxide with iron, cobalt, and nickel complexes of terdentate ligands. Inorganic Chemistry 1992;31: 3680-3682.

[224] Aga H, Aramata A, Hisaeda Y. The electroreduction of carbon dioxide by macrocyclic cobalt complexes chemically modified on a glassy carbon electrode. Journal of Electroanalytical Chemistry 1997; 437:111-118.

[225] Seshadri G, Lin C, Bocarsly AB. A new homogeneous electrocatalyst for the reduction of carbon dioxide to methanol at low overpotential. Journal of Electroanalytical Chemistry $1994 ; 372: 145-150$.

[226] Fujita E, Muckerman JT, Why is Re-Re bond formation/cleavage in $[\operatorname{Re}(b p y)(C O) 3] 2$ different from that in $[\operatorname{Re}(\mathrm{CO}) 5] 2$ ? Experimental and theoretical studies on the dimers and fragments. Inorg. Chem. 2004;43:7636-7647.

[227] Obert R, Dave BC. Enzymatic Conversion of Carbon Dioxide to Methanol: Enhanced Methanol Production in Silica Sol-Gel Matrices. J Am Chem Soc 1999; 121: 12192 12193.

[228] Aurian-Blajeni B, Taniguchi I, Bockris JOM. Photoelectrochemical reduction of carbon dioxide using polyaniline-coated silicon. Journal of Electroanalytical Chemistry and Interfacial Electrochemistry 1983;149: 291-293.

[229] Bradley MG, Tysak T. P-type silicgn-b-ased-photgelecfrochemical cells for optical energy -conversion: electrochemistry of tetraaeomacrocyclic metal complexes at illuminated p-type silicon semiconducting electrodes. Journal of Electroanalytical Chemistry and Interfacial Electrochemistry 1982;135:153-157.

[230] Parkinson BA, Weaver PF. Photoelectrochemical pumping of enzymatic $\mathrm{CO}_{2}$ reduction. Nature 1984; 309:148-149.

[231] Zhao H, Zhang Y, Zhao B, Chang Y, Li Z. Electrochemical Reduction of Carbon Dioxide in an MFC-MEC System with a Layer-by-Layer Self-Assembly Carbon Nanotube/Cobalt Phthalocyanine Modified Electrode. Environmental Science and 
Technology 2012; 46:5198-5204.

[232] Soussan L, Riess J, Erable B, Delia M-L, Bergel A, Electrochemical reduction of $\mathrm{CO}_{2}$ catalysed by Geobacter sulphur reducens grown on polarized stainless steel cathodes. Electrochemistry Communications 2013;28:27-30.

[233] Lackner KS. The thermodynamics of direct air capture of carbon dioxide. Energy 2013; 50: $38-46$

[234] Mertens J, Skelland J. Rising to the $\mathrm{CO}_{2}$ Challenge - Part 3. Hydrocarbon Eng. 2010; 15, $24-26,28,30,32-33$

[235] Kuckshinrichs W, Markewitz P, Linssen J, Zapp P, Peters M, Kçhler B, Mller TE, Leitner W, Weltweite Innovationen bei der Entwicklung von CCS-Technologien und Mçglichkeiten der Nutzung und des Recyclings von $\mathrm{CO}_{2}$, Forschungszentrum Jlich, Jlich, 2010, p. 139.

[236] Sun JT, Metcalfe IS, Sahibzada M. Deactivation of Cu/ZnO/A12O3 Methanol Synthesis Catalyst by Sintering. Ind. Eng. Chem. Res. 1999; 38: 3868-3872.

[237] Spigarelli BP, Kawatra SK. Opportunities and challenges in carbon dioxide capture. Journal of $\mathrm{CO}_{2}$ Utilization 2013; 1: 69-87.

[238] Naims H. Economics of carbon dioxide capture and utilization — a supply and demand perspective. Environ Sci Pollut Res 2016; 23:22226-22241

[239] Xin M, Shuang L, Yue L, Qinzhu G. Effectiveness of gaseous $\mathrm{CO}_{2}$ fertilizer application in China's greenhouses between 1982 and 2010. Journal of $\mathrm{CO}_{2}$ Utilization 2015; 11: 63-66.

[240] Administrative Center for China's Agenda 21, Third National Assessment Report on Climate Change (Special Report): Technical Assessment Report of Carbon Dioxide Utilization in China, Science Press, Beijing, China, 2014.

[241] Zhenzhu $\mathrm{Xu}$, Yanling Jiang, Bingrui Jia and Guangsheng Zhou. Elevated- $\mathrm{CO}_{2}$ Response of Stomata and Its Dependence on Environmental Factors. Front Plant Sci 2016;7:657. doi: 10.3389/fpls.2016.00657

[242] Fitzgerald GJ, Tausz M, O'Leary G, Mollah MR, Tausz-Posch S, Seneweera S, Mock I, Löw M, Partington DL, McNeil D, Norton RM. Elevated atmospheric $\left[\mathrm{CO}_{2}\right]$ can dramatically increase wheat yields in semi-arid environments and buffer against heat waves. Glob Chang Biol 2016;22(6):2269-84. doi: 10.1111/gcb.13263. 
[243] Eshel G, Lifschitz D, Bonfil DJ, Sternberg M. Carbon exchange in rainfed wheat fields: Effects of long-term tillage and fertilization under arid conditions. Agriculture, Ecosystems and Environment 2014;195:112-119

[244] Wang R, Peng B, Huang K. The research progress of $\mathrm{CO}_{2}$ sequestration by algal biofertilizer in China. Journal of $\mathrm{CO}_{2}$ Utilization 2015;11: 67-70

[245] Fan J-L, Zhang X, Zhang J, Peng S. Efficiency evaluation of $\mathrm{CO}_{2}$ utilization technologies in China: A super-efficiency DEA analysis based on expert survey. Journal of $\mathrm{CO}_{2}$ Utilization 2015;11:54-62

[246] Zhao H, Li H, Bao W, Wang C, Li S, Lin W. Experimental study of enhanced phosphogypsum carbonation with ammonia under increased $\mathrm{CO}_{2}$ pressure. Journal of $\mathrm{CO}_{2}$ Utilization 2015;11: 10-19

[247] El Khamlichi A, Thybaud -Research N. Chemical conversion of CO2: overview, quantification of energy and environmental benefits and economic evaluation of three chemical routes. Paris, France. 2014.

[248] Ridjan I, Mathiesen BV, Connolly D. Synthetic fuel production costs by means of solid oxide electrolysis cells. Energy 2014;76:104-13. doi:10.1016/j.energy.2014.04.002.

[249] Graves C, Ebbesen SD, Mogensen M, Lackner KS. Sustainable hydrocarbon fuels by recycling $\mathrm{CO}_{2}$ and $\mathrm{H}_{2} \mathrm{O}$ with renewable or nuclear energy. Renew Sustain Energy Rev 2011;15:1-23. doi:10.1016/j.rser.2010.07.014.

[250] Brynolf S, Taljegard M, Grahn M, Hansson J. Electrofuels for the transport sector: A review of production costs. Renew Sustain Energy Rev 2018;81:1887-905. doi:10.1016/J.RSER.2017.05.288.

[251] Hansen K, Mathiesen BV, Skov IR. Full energy system transition towards 100\% renewable energy in Germany in 2050. Renew Sustain Energy Rev 2019;102:1-13. doi:10.1016/J.RSER.2018.11.038.

[252] Bongartz D, Doré L, Eichler K, Grube T, Heuser B, Hombach LE, et al. Comparison of light-duty transportation fuels produced from renewable hydrogen and green carbon dioxide. Appl Energy 2018;231:757-67. doi:10.1016/J.APENERGY.2018.09.106.

[253] Blanco H, Nijs W, Ruf J, Faaij A. Potential for hydrogen and Power-to-Liquid in a lowcarbon EU energy system using cost optimization. Appl Energy 2018;232:617-39. doi:10.1016/J.APENERGY.2018.09.216. 
[254] Blanco H, Nijs W, Ruf J, Faaij A. Potential of Power-to-Methane in the EU energy transition to a low carbon system using cost optimization. Appl Energy 2018;232:32340. doi:10.1016/J.APENERGY.2018.08.027.

[255] Varone A, Ferrari M. Power to liquid and power to gas: An option for the German Energiewende. Renew Sustain Energy Rev 2015;45:207-18. doi:10.1016/J.RSER.2015.01.049.

[256] Hansson J, Hackl R, Taljegard M, Brynolf S, Grahn M. The Potential for Electrofuels Production in Sweden Utilizing Fossil and Biogenic CO2 Point Sources. Front Energy Res 2017;5:4. doi:10.3389/fenrg.2017.00004.

[257] Hombach LE, Doré L, Heidgen K, Maas H, Wallington TJ, Walther G. Economic and environmental assessment of current (2015) and future (2030) use of E-fuels in lightduty vehicles in Germany. J Clean Prod 2019;207:153-62. doi:10.1016/J.JCLEPRO.2018.09.261.

[258] Koytsoumpa E-I, Bergins C, Buddenberg T, Wu S, Sigurbjörnsson Ó, Tran KC, et al. The Challenge of Energy Storage in Europe: Focus on Power to Fuel. J Energy Resour Technol 2016;138:42002-10.

[259] Nielsen S, Skov IR. Investment screening model for spatial deployment of power-to-gas plants on a national scale - A Danish case. Int J Hydrogen Energy 2018. doi:10.1016/J.IJHYDENE.2018.09.129.

[260] Chi J, Yu H. Water electrolysis based on renewable energy for hydrogen production. Chinese J Catal 2018;39:390-4. doi:10.1016/S1872-2067(17)62949-8.

[261] Wulf C, Linßen J, Zapp P. Review of Power-to-Gas Projects in Europe. Energy Procedia 2018;155:367-78. doi:10.1016/J.EGYPRO.2018.11.041.

[262] Babic U, Suermann M, Büchi FN, Gubler L, Schmidt TJ. Critical Review-Identifying Critical Gaps for Polymer Electrolyte Water Electrolysis Development. J Electrochem Soc 2017;164:F387-99. doi:10.1149/2.1441704jes.

[263] Ebbesen SD, Jensen SH, Hauch A, Mogensen M. High Temperature Electrolysis in Alkaline Cells, Solid Proton Conducting Cells, and Solid Oxide Cells . - Chem Rev 2014;114:10697-734. doi:- 10.1021/cr5000865.

[264] Saba SM, Müller M, Robinius M, Stolten D. The investment costs of electrolysis - A comparison of cost studies from the past 30 years. Int J Hydrogen Energy 2018;43:1209- 
23. doi:10.1016/J.IJHYDENE.2017.11.115.

[265] Bailera M, Lisbona P, Romeo LM, Espatolero S. Power to Gas projects review: Lab, pilot and demo plants for storing renewable energy and CO2. Renew Sustain Energy Rev 2017;69:292-312. doi:10.1016/J.RSER.2016.11.130.

[266] Carbon Recycling international. George Olah Renewable Methanol Plant 2012. http://carbonrecycling.is/george-olah/ (accessed October 19, 2018).

[267] Jendrischik M. Sunfire produces sustainable cruide oil alternative Dresden, Germany 2017.

[268] Horizon2020 project. MefCO2 n.d. http://www.mefco2.eu/project_progress.php (accessed November 28, 2018).

[269] Horizon2020 project. FReSMe n.d. http://www.fresme.eu/about.php (accessed November 28, 2018).

[270] Sunfire to build 8000 tonne-per-annum power-to-liquid facility in Norway | Bioenergy International n.d. https://bioenergyinternational.com/biofuels-oils/sunfire-build-8-000tonne-per-annum-power-liquid-facility-norway (accessed November 28, 2018).

[271] Research and Innovation D-G. Final Report of the High-Level Panel of the European Decarbonisation Pathways Initiative, Brussels, Belgium, 2018. doi:10.2777/476014.

[272] Krey V, Luderer G, Clarke L, Kriegler E. Getting from here to there - energy technology transformation pathways in the EMF27 scenarios. Clim Change 2014;123:369-82. doi:10.1007/s10584-013-0947-5.

[273] Kuramochi T, Ramírez A, Turkenburg W, Faaij A. Techno-economic prospects for CO2 capture from distributed energy systems. Renew Sustain Energy Rev 2013;19:328-47. doi:10.1016/J.RSER.2012.10.051.

[274] Ju Y, Lee CH. Evaluation of the energy efficiency of the shell coal gasification process by coal type. Energy Convers Manag 2017;143:123-36. doi:10.1016/j.enconman.2017.03.082.

[275] Leung DYC, Caramanna G, Maroto-Valer MM. An overview of current status of carbon dioxide capture and storage technologies. Renew Sustain Energy Rev 2014;39:426-43. doi:10.1016/j.rser.2014.07.093.

[276] House KZ, Harvey CF, Aziz MJ, Schrag DP. The energy penalty of post-combustion $\mathrm{CO}_{2}$ capture \& storage and its implications for retrofitting the U.S. installed base. Energy 
Environ Sci 2009;2:193-205. doi:10.1039/b811608c.

[277] Goto K, Yogo K, Higashii T. A review of efficiency penalty in a coal-fired power plant with post-combustion CO2 capture. Appl Energy 2013;111:710-20. doi:10.1016/J.APENERGY.2013.05.020.

[278] Nord LO, Bolland O. Plant flexibility of a pre-combustion CO2 capture cycle. Energy Procedia 2011;4:2556-63. doi:10.1016/J.EGYPRO.2011.02.153.

[279] Abdilahi AM, Mustafa MW, Abujarad SY, Mustapha M. Harnessing flexibility potential of flexible carbon capture power plants for future low carbon power systems: Review. Renew Sustain Energy Rev 2018;81:3101-10. doi:10.1016/J.RSER.2017.08.085.

[280] Cohen SM, Rochelle GT, Webber ME. Optimizing post-combustion CO2 capture in response to volatile electricity prices. Int J Greenh Gas Control 2012;8:180-95. doi:10.1016/J.IJGGC.2012.02.011.

[281] Montañés RM, Korpås M, Nord LO, Jaehnert S. Identifying Operational Requirements for Flexible CCS Power Plant in Future Energy Systems. Energy Procedia 2016;86:2231. doi:10.1016/J.EGYPRO.2016.01.003.

[282] Danish Energy Agency, ENERGINET. Technology Data for Energy Plants Generation of Electricity and District Heating. Copenhagen, Denmark, 2016. doi:ISBN: 978-877844-940-5.

[283] Koo J, Han K, Yoon ES. Integration of CCS, emissions trading and volatilities of fuel prices into sustainable energy planning, and its robust optimization. Renew Sustain Energy Rev 2011;15:665-72. doi:10.1016/j.rser.2010.07.050.

[284] Kang CA, Brandt AR, Durlofsky LJ. Optimal operation of an integrated energy system including fossil fuel power generation, $\mathrm{CO}_{2}$ capture and wind. Energy 2011;36:6806-20. doi:10.1016/j.energy.2011.10.015.

[285] de Souza Noel Simas Barbosa L, Hytönen E, Vainikka P. Carbon mass balance in sugarcane biorefineries in Brazil for evaluating carbon capture and utilization opportunities. Biomass and Bioenergy 2017;105:351-63. doi:10.1016/j.biombioe.2017.07.015.

[286] Volkart K, Bauer C, Boulet C. Life cycle assessment of carbon capture and storage in power generation and industry in Europe. Int J Greenh Gas Control 2013;16:91-106. doi:10.1016/J.IJGGC.2013.03.003. 
[287] Workshop on Life Cycle Analysis for Carbon Capture \&amp; Utilisation - 6 June 2017 - European Commission n.d. https://ec.europa.eu/energy/en/content/workshop-lifecycle-analysis-carbon-capture-utilisation-6-june-2017 (accessed November 29, 2018).

[288] Cuéllar-Franca RM, Azapagic A. Carbon capture, storage and utilisation technologies: A critical analysis and comparison of their life cycle environmental impacts. J CO2 Util 2015;9:82-102. doi:10.1016/J.JCOU.2014.12.001.

[289] Danish Energy Agency, ENERGINET. Technology Data for Renewable Fuels. Copenhagen, Denmark, 2017.

[290] Schmidt O, Gambhir A, Staffell I, Hawkes A, Nelson J, Few S. Future cost and performance of water electrolysis: An expert elicitation study. Int J Hydrogen Energy 2017;42:30470-92. doi:10.1016/J.IJHYDENE.2017.10.045.

[291] Durmaz T. The economics of CCS: Why have CCS technologies not had an international breakthrough? Renew Sustain Energy Rev 2018;95:328-40. doi:10.1016/J.RSER.2018.07.007.

[292] Sun L, Chen W. Study on DSS for CCUS Source-Sink Matching. Energy Procedia 2015;75:2311-6. doi:10.1016/j.egypro.2015.07.428.

[293] Frederick J, Tapia D, Lee J, Ooi REH, Foo DCY, Tan RR. A review of optimization and decision-making models for the planning of $\mathrm{CO} 2$ capture, utilization and storage ( CCUS ) systems. Sustain Prod Consum 2017;13:1-15. doi:10.1016/j.spc.2017.10.001.

[294] Kasivisvanathan H, Barilea IDU, Ng DKS, Tan RR. Optimal operational adjustment in multi-functional energy systems in response to process inoperability. Appl Energy 2013;102:492-500. doi:10.1016/J.APENERGY.2012.07.052.

[295] Franklin MOJ. Carbon Capture , Utilization , and Storage : An Update. Stanford Univ Stanford, USA, 2018.

[296] Child M, Kemfert, C, Bogdanov D, Breyer C. Flexible electricity generation, grid exchange and storage for the transition to a $100 \%$ renewable energy system in Europe. Renew Energy 2019;139:80-101. doi.org:10.1016/j.renene.2019.02.077 